\title{
Review Article \\ Oxidative Stress and Redox Modulation Potential in Type 1 Diabetes
}

\author{
Meghan M. Delmastro ${ }^{1,2}$ and Jon D. Piganellii, 2,3 \\ ${ }^{1}$ Diabetes Institute, Division of Immunogenetics, Department of Pediatrics, Children's Hospital of Pittsburgh, \\ University of Pittsburgh School of Medicine, Pittsburgh, PA 15224, USA \\ ${ }^{2}$ Department of Immunology, University of Pittsburgh School of Medicine, Pittsburgh, PA 15224, USA \\ ${ }^{3}$ Rangos Research Center, Department of Pediatrics, Children's Hospital of Pittsburgh of UPMC, 4401 Penn Avenue, \\ Pittsburgh, PA 15224, USA
}

Correspondence should be addressed to Jon D. Piganelli, jdp51@pitt.edu

Received 18 January 2011; Accepted 9 March 2011

Academic Editor: Nick Giannoukakis

Copyright (c) 2011 M. M. Delmastro and J. D. Piganelli. This is an open access article distributed under the Creative Commons Attribution License, which permits unrestricted use, distribution, and reproduction in any medium, provided the original work is properly cited.

\begin{abstract}
Redox reactions are imperative to preserving cellular metabolism yet must be strictly regulated. Imbalances between reactive oxygen species (ROS) and antioxidants can initiate oxidative stress, which without proper resolve, can manifest into disease. In type 1 diabetes (T1D), T-cell-mediated autoimmune destruction of pancreatic $\beta$-cells is secondary to the primary invasion of macrophages and dendritic cells (DCs) into the islets. Macrophages/DCs, however, are activated by intercellular ROS from resident pancreatic phagocytes and intracellular ROS formed after receptor-ligand interactions via redox-dependent transcription factors such as NF- $\kappa$ B. Activated macrophages/DCs ferry $\beta$-cell antigens specifically to pancreatic lymph nodes, where they trigger reactive $\mathrm{T}$ cells through synapse formation and secretion of proinflammatory cytokines and more ROS. ROS generation, therefore, is pivotal in formulating both innate and adaptive immune responses accountable for islet cell autoimmunity. The importance of ROS/oxidative stress as well as potential for redox modulation in the context of T1D will be discussed.
\end{abstract}

\section{Introduction}

Oxidation-reduction or redox reactions are pivotal to maintaining life through respiration, metabolism, and energy supply. Mitochondria, which are known to be the powerhouses of the cell, possess the ability to utilize nutrients to generate energy (redox potential) via the electron transport chain, which donates electrons to oxygen to yield ATP and $\mathrm{H}_{2} \mathrm{O}$ $[1,2]$. Consequently, oxygen free radicals, known as superoxide $\left(\mathrm{O}_{2}^{-}\right)$, are nonenzymatically leaked from the mitochondria and react with other molecules to create reactive oxygen species (ROS) such as hydrogen peroxide $\left(\mathrm{H}_{2} \mathrm{O}_{2}\right)$, peroxynitrite $\left(\mathrm{ONOO}^{-}\right)$, and hydroxyl radical $\left(\mathrm{OH}^{-}\right)$, all of which can alter DNA, proteins, carbohydrates, and nucleic acids [3-5] and may eventually lead to irreversible damage. The inability of a cell's antioxidant defenses to overcome oxidative injury and accretion of severe ROS-mediated damage over time will eventually lead to cell death [5-7]. In order to maintain a reduced environment, several cellular antioxidant defenses are in place, including glutathione, glutathione peroxidase, catalase, and three different superoxide dismutase (SOD) enzymes: SOD1, 2, and 3, located in different subcellular and extracellular locations. A basal level of "accidental" superoxide is accumulated in healthy individuals $[1,8]$, which has been widely hypothesized to be responsible for aging and the associated pathologies [9-11]. However, oxidative stress occurs from an imbalance between ROS and antioxidant actions. During chronic oxidative stress caused by environmental factors (i.e., UV light, ionizing radiation, toxic substances), infections, or lack of dietary antioxidants, an inequity of cellular reducing equivalents capable of detoxifying the increased burden of ROS has marked effects on normal cellular processes. However, in times of oxidative stress, normal cellular respiration is also still functioning, resulting in dysregulated mitochondrial free radical production and disparity between ROS generation and antioxidant 
defenses $[6,12]$. The combination of stress-induced and conventional mitochondrial dysfunction can manifest into disease states, including cancer [13-15], rheumatoid arthritis $[16,17]$, neurological disorders [18-21], pulmonary diseases [22], and type 1 diabetes [23-26].

\section{Redox and Inflammation}

What once was thought to be solely derived from the mitochondria, reactive oxygen species have now been shown to be produced by an important family of primarily immune system-associated enzymes [27-29]. The NADPH oxidase (NOX) family of enzymes is designed to combine NADPH and oxygen to actively generate superoxide. Activated phagocytes, such as macrophages, monocytes, and dendritic cells (DCs), as well as neutrophils, form ROS within the phagosomal membrane for efficient killing of a wide array of invading pathogens [30]. The protection afforded by the phagocytes is crucial, but not without side effects. Production of highly permeable reactive oxygen species (i.e., $\mathrm{H}_{2} \mathrm{O}_{2}$ ) causes leakage of these molecules from phagocytes and therefore, unwanted effects on bystander cells [31, 32]. In an environment high in oxidative stress, these bystander reactions drive increased activation of the immune system, cell damage, and progression to disease. For example, NOX-derived ROS have been shown to stimulate mitogenic signaling and proliferation $[33,34]$, which can have potential deleterious consequences on the promotion of tumorigenesis $[35,36]$ and in the context of autoimmunity, can lead to $\mathrm{T}$ cell expansion [37]. Additionally, $\mathrm{H}_{2} \mathrm{O}_{2}$ can augment monocyte chemokine receptor surface expression critical for migration to sites of infection and inducing inflammation [38] as well as can promote VEGF signaling to trigger angiogenesis, with implications in cancer and tumor progression [39]. Furthermore, ROS generated from both mitochondria and NADPH oxidase complexes can also act intra-cellularly as well as inter-cellularly as signal transduction molecules. Hydrogen peroxide has been suggested to inactivate protein phosphatases [40], as well as to activate protein tyrosine kinases $[41,42]$ and metalloproteases through the oxidation of critical cysteine residues [43, 44]. Phosphatases such as SHP-1 serve to decrease inflammation by inhibiting tyrosine kinase activity, yet this type of regulation is lost upon cysteine oxidation [45-48]. Similarly, latent metalloproteases require oxidation for activation and, in the presence of hypochlorous acid (HOCL) and $\mathrm{H}_{2} \mathrm{O}_{2}$, secretion of chemotactic mediators (L-selectin and proinflammatory $\mathrm{TNF} \alpha$ ) is highly increased [49], thus enhancing inflammation. In addition, $\mathrm{H}_{2} \mathrm{O}_{2}$ has been demonstrated to freely cross the plasma membrane and activate NF- $\kappa \mathrm{B}$, a redox-dependent transcription factor $[50,51]$. NF- $\kappa$ B plays a major role in immunity by promoting proinflammatory cytokine production, cell proliferation, and inflammation. In general, receptor-ligand interactions are known to generate $\operatorname{ROS}[52,53]$. In the immune system specifically, LPS interaction with Toll-like receptor 4 (TLR4) has been shown to facilitate the binding of TLR4 to NADPH oxidase 4 (Nox4) and subsequently release ROS [54], resulting in the activation of NF- $\kappa \mathrm{B}$ and generation of proinflammatory cytokines IL- $1 \beta$ and TNF $\alpha$ [53].
In a highly oxidized environment, the binding of pathogens to innate cell receptors can lead to hyperresponsiveness [55], suggesting inflammation is secondary to oxidative stress $[25,56]$. Not only are phagocytic cells critical for early pathogen recognition through receptor-ligand interaction, they are also necessary for activation of the adaptive immune response. Following antigen recognition by phagocytic antigen-presenting cells (APC), an adaptive immune response is acquired in secondary lymphoid organs through synapse formation of APCs with lymphocytes, as well as from critical innate-derived ROS and third signal proinflammatory cytokines (TNF $\alpha$, IL-1 $\beta$ ) enhancing Tcell activation, proliferation, and effector function [37, 57]. Within this interaction, the $\mathrm{H}_{2} \mathrm{O}_{2}$ made by the phagocytes is able to traverse the synapse and act upon the T cells, at concentrations ranging from $10-100 \mu \mathrm{M}[58,59]$, resulting in a feed-forward mechanism stimulating T-cell-specific $\mathrm{NF}-\kappa \mathrm{B}$ activity and subsequent proinflammatory cytokine production. Similar effects of ROS are also seen on B cells [60]. Moreover, antigen stimulation of the TCR also drives endogenous production of $\mathrm{H}_{2} \mathrm{O}_{2}$ through the T cell's own NOX enzyme $[28,61]$. Intracellular $\mathrm{H}_{2} \mathrm{O}_{2}$ can then signal and lead to T-cell proliferation, apoptosis $[61,62]$, and in conjunction with proinflammatory cytokines, promote Tcell effector function $[37,52,63]$. Therefore, in the presence of oxidative stress, an inability to balance the oxidation with antioxidant enzymes can drive chronic inflammation from both the innate and adaptive arms of the immune response [64], manifesting into many clinically relevant diseases, particularly type 1 diabetes.

\section{Oxidative Stress and Type 1 Diabetes}

Type 1 diabetes or insulin-dependent diabetes mellitus (T1D) is an autoimmune disorder involving immunemediated recognition of islet $\beta$-cells by autoreactive T cells, which leads to the liberation of ROS and proinflammatory cytokines, resulting in the destruction of pancreatic $\beta$-cells in the islets of Langerhans and loss of insulin secretion. Patients with T1D must constantly prevent hyperglycemia by administering exogenous insulin or in the situation of severe hyperglycemic unawareness, by undergoing islet transplantation. Despite a multitude of efforts in trying to specify the exact etiology, the cause of T1D is still under debate. The combinatorial effects of genetic susceptibility, environmental factors, and dietary deficiencies are known to contribute to disease origin; however, the impact of oxidative stress in a genetically susceptible individual is of particular interest. Oxidative stress, as stated above, occurs when the generation of ROS overcomes the scavenging abilities of antioxidants. Such instances may be mediated by genetic lack of antioxidant enzymes as well as environmental triggers like viral infections. Overall, oxidative stress has been linked to $\beta$ cell cytotoxicity [65-67] and has been suggested to play a role in T1D pathology [68-71]. Several studies show that the total serum antioxidant status, as measured by urate, Vitamin C, and total plasma antioxidant levels, of prediabetic and T1D patients is lower in comparison to age-matched controls [72, 73], which inevitably leads to greater oxidative modification 
of proteins and lipids [74]. Other literature illustrates a connection between viruses, ROS production, and type 1 diabetes onset. Gamble et al. demonstrated a positive correlation between type 1 diabetes onset and Coxsackie B4 virus infection through antibody titer measurements $[75,76]$. Furthermore, such infections have been shown to cause indirect [77] and direct $\beta$-cell damage [78] and to stimulate the $\beta$-cells into secreting inflammatory mediators themselves [79]. ROS are made following viral infection from activated phagocytes $[80,81]$, as mentioned previously, and work to not only cause cellular injury but also can activate inflammatory, redoxdependent transcription factors, such as NF- $\kappa \mathrm{B}$, perpetuating inflammation. Viral-mediated ROS production or a reduction in antioxidants can have severe consequences as $\beta$ cells are more prone to oxidative damage than most other tissues. The $\beta$-cell mitochondria have exceptionally low levels of glutathione peroxidase, superoxide dismutase, and catalase activity [24, 82-84]. Because of this low antioxidant defense, $\beta$-cells can be clearly disrupted by oxidative stress and, in genetically predisposed individuals, results in easy targets for a subsequent cytokine-mediated autoimmune attack.

Mitochondrial and NOX-derived ROS both have implications in $\beta$-cell destruction and T1D. Increased glucose causes rapid induction of the tricarboxylic acid (TCA) cycle within the $\beta$-cell mitochondria, which can lead to augmented ROS production [85]. The superoxide leaked from mitochondria can then form $\mathrm{H}_{2} \mathrm{O}_{2}$ and work to uncouple glucose metabolism from insulin secretion [86]. Ultimately, high levels of mitochondrial ROS can cause $\beta$-cell death $[87,88]$. Intriguingly, models of T1D induce disease by generating toxic amounts of ROS within the islets (i.e., streptozotocin and alloxan) [89]. Alloxan is easily taken up by $\beta$-cells [90], where it is reduced into dialuric acid and subsequently reoxidized to establish a redox cycle [91]. ROS generated by alloxan treatment have been shown to promote islet $\beta$-cell DNA fragmentation, culminating in cell death [92]. In contrast, an alloxan-resistant strain of mice, the ALR mouse, shows increased ROS dissipation and resistance to islet destruction $[23,93,94]$, further implicating the importance of oxidative stress and T1D. Streptozotocin (STZ), on the other hand, causes $\beta$-cell DNA alkylation and eventually drains the cellular $\mathrm{NAD}^{+}$and ATP source in an effort to repair the DNA [95]. Xanthine oxidase is then able to utilize dephosphorylated ATP as a substrate for superoxide production [96]. Additionally, STZ metabolism increases the levels of islet cell nitric oxide (NO) [97], which together with superoxide can generate peroxynitrite $\left(\mathrm{ONOO}^{-}\right)$. Detection of peroxynitrite in prediabetic nonobese diabetic mouse (NOD) islets suggests importance of this ROS in $\beta$-cell death [71]. Similarly, NOX enzymes have been detected within the pancreatic $\beta$-cells $[98,99]$. Hyperglycemia can increase the assembly of NOX enzymes through its p47phox subunit, and therefore, enhance superoxide generation [100] and facilitate $\beta$-cell death.

\section{Immunology of T1D}

Autoimmune diabetes onset is preceded by infiltration of immune cells into the pancreatic islets. Ultimately, a breach in tolerance to self-antigens allows for autoreactive T cells to become activated and attack the $\beta$-cells, resulting in the loss of insulin secretion. However, innate immune cells, such as macrophages and DCs, are of the first cells to enter the islets during insulitis [101, 102]. Although resident macrophages are present in the pancreas at all times, acquisition of antigen is required for macrophage activation and the production of cytokines. As described above, genetic and environmental factors can lead to cell destruction, releasing $\beta$-cell-specific antigens as well as ROS [103]. Macrophages will phagocytose dying $\beta$-cells and present antigen in the context of their MHC molecules. In humans, specific HLA molecules HLADR3 and DR4 are correlated with a susceptibility to T1D $[103,104]$. Moreover, the ROS created by the initial insult to the islets are able to stimulate the activation of redoxdependent NF- $\kappa$ B and other transcription factors within the macrophages [105]. Activated macrophages secrete a mixture of proinflammatory cytokines such as TNF $\alpha$, IL-6, IL- $1 \beta$, and ROS, which can start to damage the pancreatic $\beta$-cells [106-108]. IL-1 $\beta$ can cause extensive cytolysis in $\beta$-cells [109] through the upregulation of iNOS and subsequent generation of nitric oxide (NO) $[110,111]$, whereas TNF $\alpha$ enhances IL- $1 \beta$-mediated islet destruction and helps activate APCs and T cells [112-114], but does not cause direct $\beta$-cell apoptosis in vivo [114].

ROS and cytokines released by APCs not only promote $\beta$-cell damage, but also help to generate an adaptive immune response, which in T1D, is the crucial step in autoimmune destruction. It is well established that chronic elicitation of antigens to innate immune cells in a highly oxidized environment will lead to MHC-peptide presentation, perpetuating an adaptive immune response $[115,116]$ (Figure 1).

In the context of continuous $\beta$-cell ablation, macrophages can phagocytose dying cells and migrate to the pancreatic lymph node where they interact with naïve T-cells. It is this aforementioned synapse that enables T-cell proliferation and effector function to occur. In the presence of all three necessary signals: (1) MHC-peptide, (2) costimulation, and (3) soluble third signal, in this case consisting of ROS, IL$1 \beta$, and TNF $\alpha$, T cells become activated via NFAT and NF- $\kappa$ B [117-121]. Furthermore, IL-12 released from macrophages can differentiate $\mathrm{CD} 4^{+} \mathrm{T}$ cells into the TH1 lineage via signaling through STAT4 [122-125]. CD4 ${ }^{+} \mathrm{TH} 1$ cells then home to the site of antigen production, the $\beta$-cells, and call in other $\mathrm{T}$ cells and more APCs through the secretion of IFN $\gamma$. IFN $\gamma$ has some indirect effects on $\beta$-cells, including potentiating the maturation of pancreatic APCs, which can then elicit an even greater T-cell response [126]. Additionally, neutralization of IFN $\gamma$ in NOD mice has been shown to reduce both diabetes and insulitis [127], whereas IFN $\gamma$ R-deficient NOD mice demonstrate delayed insulitis, but do not develop T1D [128]. Proinflammatory cytokines TNF $\alpha$, IL- $1 \beta$, and IFN $\gamma$ all play a role in $\beta$-cell death primarily through activation of redoxregulated transcription factors NF- $\kappa$ B and STAT1 [129-131]. Combinations of TNF $\alpha$ with IFN $\gamma$ or IL- $1 \beta$ are necessary for primary murine $\beta$-cell death [132], and TNF $\alpha / \mathrm{IFN} \gamma$ act synergistically to activate the stress-activated proapoptotic JNK/SAPK pathway, which promotes $\beta$-cell apoptosis via p53 and intracellular ROS [133]. The activation of NF- $\kappa$ B can 


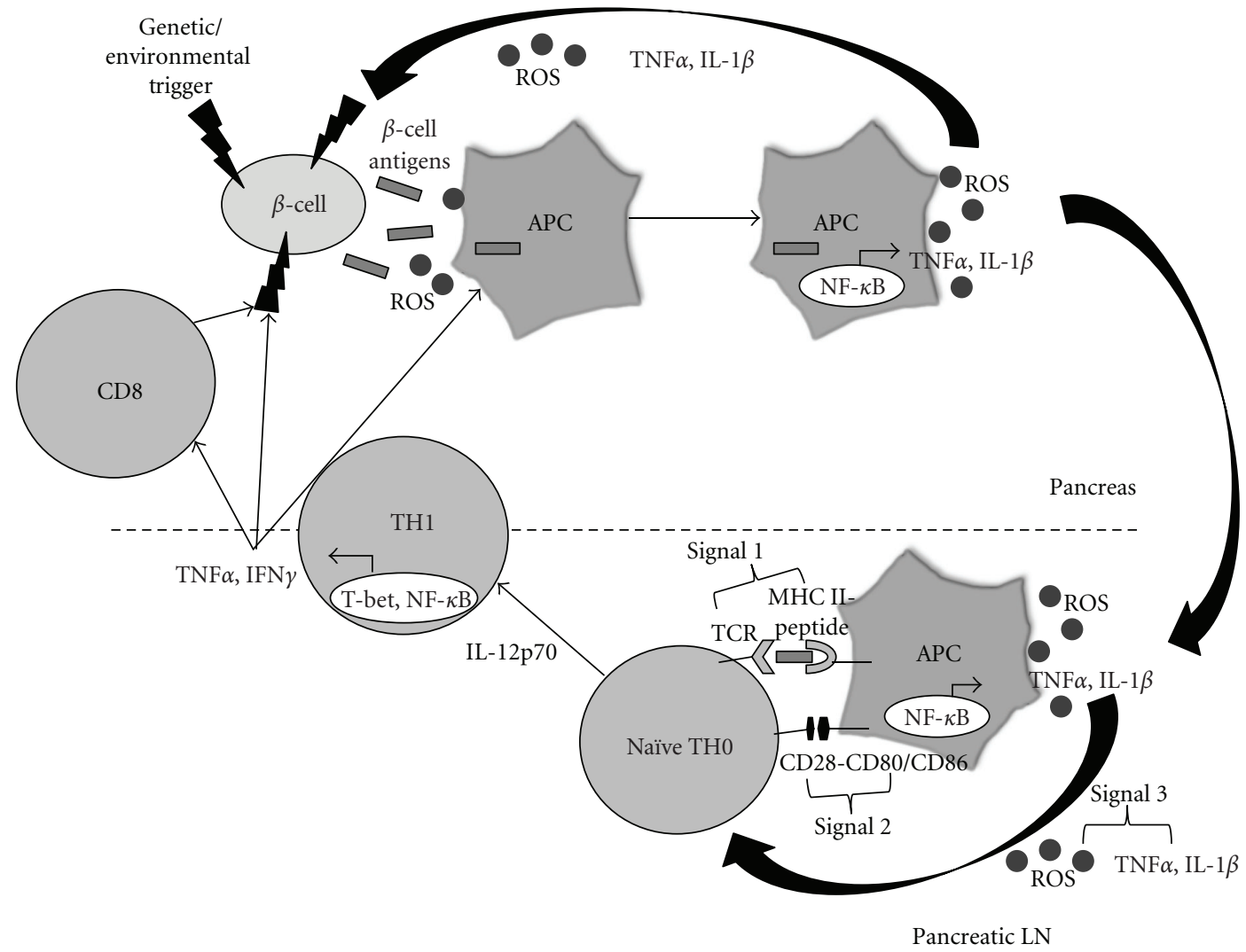

FIGURE 1: Role of redox in the immunopathology of type 1 diabetes. An initial genetic or environmental insult to the beta cell triggers the release of beta cell antigens as well as the production of ROS. Beta cell antigens are phagocytosed, and ROS are able to stimulate redox-dependent transcription factors such as NF- $\kappa \mathrm{B}$, which leads to APC activation and cytokine secretion. ROS and proinflammatory cytokines secreted by APCs act as the third signal within the T-cell-APC immunological synapse, which occurs in the pancreatic lymph node. ROS play a critical role in the progression of naïve TH0 cells to cytokine-secreting TH1 cells. Release of IFN $\gamma$ by TH1 cells then works directly on the beta cells as well as activates more APCs and CD8 cells, all of which can impart deleterious effects on the islets.

also increase iNOS and Fas expression, potential inducers of cell death, while downregulating the antiapoptotic Bcl-2 gene [134]. Apoptosis of $\beta$-cells is also mediated partially by T-cell expression of Fas ligand, TNF $\alpha$, and perforin/granzyme [114, 134]. Specifically, $\mathrm{CD} 4^{+} \mathrm{T}$ cells are thought to be sufficient for T1D onset $[135,136]$, whereas $\mathrm{CD} 8^{+} \mathrm{T}$ cells seem to play a lesser role in the final stage of autoimmune destruction [137]. It is known, however, that synergy between both CD4 and CD8 T cells results in absolute transfer of diabetes in rodent models $[138,139]$. Although specific to the model of autoimmune diabetes, TNF $\alpha$ secretion from $\mathrm{CD} 4^{+} \mathrm{T}$ cells can activate TNFR1 on $\beta$-cells and cause apoptosis [140], while $\mathrm{CD}^{+} \mathrm{T}$ cells can kill NOD $\beta$-cells by a Fasdependent mechanism [141] or by perforin release [142]. Ultimately, T-cell exacerbation of $\beta$-cell death comes from endogenous generation of ROS and cytokines following APC activation [143] that can perpetuate islet destruction through a feed forward mechanism. Overall, ROS are crucial in not only activating the initial infiltrating macrophages and DCs [144] via the common denominator NF- $\kappa \mathrm{B}$, but also for subsequently driving an adaptive TH1 immune response that is necessary for total ablation of $\beta$-cells and progression to T1D $[134,136]$. Therefore, therapies would be most beneficial if there was not only protection of the $\beta$-cells from ROS, but also inhibition of the ROS-mediated autoimmune attack, possibly by preventing NF- $\kappa \mathrm{B}$ activation, ensuing inflammation, and the initiation of the adaptive immune response.

\section{Controlling Redox in T1D}

Glutathione peroxidase (GPX), superoxide dismutase (SOD), and catalase are categorized as the most crucial antioxidant enzymes; however, islets inherently contain only a fraction of the enzymatic activities in comparison to liver, which possesses the highest abundance [145]. Because of the low antioxidant defenses present in pancreatic islets, therapeutic strategies to enhance antioxidants and reducing capabilities are of utmost importance. Studies utilizing overexpression of GPX1, SOD1 (Cu/Zn SOD), SOD2 (MnSOD), or SOD mimetic administration in insulinoma cell lines such as NIT-1 and INS-1 afforded protection from ROS and reactive nitrogen species (RNS) in vitro $[25,146$, 147]. Usage of SOD mimetics in other inflammatory models has also demonstrated diminutions in proinflammatory cytokines $[148,149]$. Furthermore, stable transfection of 
insulin-producing RINm5F cells with GPX, catalase, and $\mathrm{Cu} / \mathrm{Zn}$ SOD resulted in defenses against cytokine toxicity imparted by the combination of IL-1 $\beta$, TNF $\alpha$, and IFN $\gamma$ [150]. Antioxidant overexpression has been linked to not only protection against ROS and cytokines, but also to enhanced cell proliferation and decreased death. PDX1, a transcription factor necessary for $\beta$-cell differentiation, survival, and insulin synthesis [151], is also very responsive to ROS [152], where high oxidation causes a cytoplasmic relocation of PDX1 out of the nucleus, increased degradation of the protein, and subsequent dysfunction of $\beta$-cells [153, 154]. By alleviating ROS within the islets, PDX1 protein has exhibited stability and enhanced function in type 2 diabetes models [155], which can also have implications in T1D for stabilizing $\beta$-cell function and survival. Other experiments utilize transgene or adenoviral technology to overexpress antioxidant genes within the $\beta$-cells to specifically show islet-mediated versus autoimmune protection from T1D. These studies have elicited conflicting results. For example, overexpression of metallothionein and catalase in $\beta$-cells was unable to delay or inhibit spontaneous diabetes onset within NOD mice and promoted reduced activation of the PDX1 survival pathway [156]. Metallothionein proteins are intracellular, cysteine-rich molecules with high redox potential [157]. Similarly, transgenic expression of extracellular SOD in $\beta$-cells does not confer any difference in T1D incidence in comparison to control NOD mice [158]. These results suggest that basal levels of ROS production are necessary for $\beta$-cell function, possibly by triggering appropriate insulin signaling and regulating cell survival [159]. In contrast, overexpression of thioredoxin, a redox-regulated protein which helps repair ROS-damaged proteins and DNA, constitutes protection of $\beta$-cells from autoimmune and STZinduced diabetes [160]. $\beta$-cell-specific transgenic expression of catalase and metallothionein is also able to shield isolated islets from hydrogen peroxide and reduce the effects of STZ treatment [161-163]. Transgenic expression of heme oxygenase-1, which has crucial cytoprotective functions against oxidative stress and inflammation, can improve insulitis and spontaneous diabetes in NOD mice [164], and alloxan-induced diabetes is also reduced following overexpression of $\mathrm{Cu} / \mathrm{Zn} \mathrm{SOD}$ in $\beta$-cells [165]. Moreso, precedence for the importance of enhancing islet-associated antioxidant levels has been demonstrated at the genetic level, in which mice resistant to alloxan treatment (ALR mice) exhibit protection from diabetes $[94,166]$. This finding particularly helps further justify the need for therapeutic discovery and necessary experiments to determine druggable targets based upon modulation of antioxidant function.

Systemic administration of antioxidants, in comparison to overexpression studies, shows more consistency in ameliorating T1D. Administration of $16 \mathrm{mg} / \mathrm{kg} /$ day of a potent antioxidant to young NOD mice resulted in a reduction of diabetes incidence from $89 \%$ in controls to $44 \%$ in the treated animals [167]. Furthermore, after a multiple low dose administration of STZ, addition of zinc sulphate to the drinking water of animals was able to increase metallothionein levels, inhibiting the onset of T1D [168], whereas intraperitoneal injections of butylated hydroxyanisole (BHA) antioxidant were able to attenuate the production of proinflammatory cytokines by islets and macrophages, thereby lowering insulitis and hyperglycemia [169]. Such uniformity in these results versus the transgenic expression of multiple antioxidants, as discussed above, may relate to the ability of systemic therapies to not only protect the $\beta$-cells but to also inhibit immune system activation and inflammation. Adenoviral delivery of systemic heme oxygenase to NOD mice decreased insulitis and T1D incidence; however, this alleviation was associated with a decrease in mature DCs and TH1 effector function [170]. Additionally, ALR mice resistant to alloxan-induced diabetes contain specific genetic modifications conferring systemic elevation of antioxidants, resulting in neutrophils with reduced superoxide bursts [171]. In an in vitro system using the antioxidant probucol, which can delay alloxan-induced [172] and spontaneous diabetes in rats [173], macrophages exhibit decreased $\mathrm{H}_{2} \mathrm{O}_{2}$ production, thus maintaining islet viability [174]. Further reports on the effects of systemic antioxidants on innate immunity include studies from our lab utilizing metalloporphyrinbased catalytic antioxidants (CA) with bone marrow-derived macrophages. The CA houses a metal center that catalyzes superoxide dismutation, mimicking SOD activity $[175,176]$, and is able to scavenge a broad range of ROS including $\mathrm{O}_{2}^{-}, \mathrm{H}_{2} \mathrm{O}_{2}, \mathrm{ONOO}^{-}$, and lipid peroxyl radicals [53, 177, 178]. Following treatment with CA and LPS stimulation of macrophages, the production of nitrite $\left(\mathrm{NO}_{2}^{-}\right), \mathrm{O}_{2}^{-} \mathrm{TNF} \alpha$, and IL- $1 \beta$ was significantly reduced in comparison to control $[25,53]$. This effect was mediated by the ability of CA to oxidize the p50 subunit of NF- $\kappa \mathrm{B}$ within the nucleus, inhibiting its binding to DNA and subsequent transcription of proinflammatory cytokines [53]. Redox modulation of transcription factor DNA binding has previously been demonstrated for NF- $\kappa \mathrm{B}$ as well as other eukaryotic molecules $[179,180]$. Inhibition of NF- $\kappa$ B has been well established as an effective method of thwarting the immune response and resolving inflammation to maintain $\beta$-cell integrity $[181,182]$; however, we are the first to illustrate a link between metalloporphyrin catalytic antioxidants, blockade of NF- $\kappa$ B activation, and delayed autoimmune diabetes, as described below.

The activation of macrophages and $\mathrm{T}$ cells relies on oxidative stress, which ultimately leads to the progression of T1D. Based upon this fact, CA was also investigated in the context of CD4 and CD8 T cells. The BDC-2.5 TCRTg TH1 cell clone, which has recently been described as specific for the protein ChgA, a member of the granin family of neuroendocrine secretory proteins [183], causes rapid transfer of diabetes into NOD.scid recipients [184]. By utilizing this method, pretreatment of NOD.scid mice with CA prior to adoptive transfer of the BDC-2.5 clone inhibits the infiltration of $\mathrm{T}$ cells into the pancreas, significantly delaying T1D onset. Moreover, APC-dependent BDC-2.5 $\mathrm{T}$ cell proliferation and IFN $\gamma$ production are also reduced after in vitro CA treatment [25]. To further delineate the mechanism of diminished T-cell effector function, in vivo treatment of $\mathrm{NOD}$ and $\mathrm{BDC}-2.5$ TCR-Tg mice with CA was able to decrease innate-derived third signal synthesis, primarily consisting of TNF $\alpha$, resulting in antigenspecific T cell hyporesponsiveness [37]. Similar results were 
found upon CA treatment in the context of CD8 T cells, reducing proliferation, cytokine production, and cytolytic effector molecules of CTLs [185]. Interestingly, by inhibiting NADPH oxidase in NOD animals (NOD.Ncf1 ${ }^{m 1 J}$ ) in an effort to genetically mimic systemic CA administration, not only is NOX-derived superoxide production eliminated, but $\mathrm{T}$ cells show reduced $\mathrm{TH} 1$ responses, granting protection from $\mathrm{T} 1 \mathrm{D}$ onset [120]. Earlier studies by Chaudhri et al. supported our experimentation by demonstrating attenuation of Tcell proliferation and IL-2R expression following antioxidant treatment $[186,187]$. Such findings point to the possibility and importance of redox modulation in not only regulating the innate immune cells, but also impacting the $\mathrm{T}$ cells which formulate an adaptive immune response crucial for the autoimmune attack in T1D (Figure 2).

In addition to decreasing oxidative stress imposed on the islets, which can directly damage $\beta$-cells or indirectly stimulate the autoreactive immune response to become activated, redox modulation may also be useful for decreasing the unyielding ER stress within the $\beta$-cells. Because the $\beta$ cells are a constant source of insulin and insulin must be folded properly for secretion, the importance of balancing a high protein-folding load with survival of the cells increases substantially in comparison to other nonsecretory cells [188]. An overload of misfolded proteins may eventually result in cell death, if not properly resolved. An early study by Lo et al. highlighted the susceptibility of $\beta$-cells to ER stress by overexpressing MHC class II proteins in islets, essentially overwhelming the protein folding machinery and leading to apoptosis [189]. Other more recent studies show biochemical connections between ER stress-induced apoptosis and $\beta$-cell death, through both calcium-dependent and independent molecules [190-192]. To reconcile protein misfolding within the ER, the unfolded protein response, or UPR, is consequently triggered [193, 194]. The UPR acts as a backup mechanism to protect cells from accumulating unfolded proteins and to restore the balance between the protein folding machinery and the secretory pathway [195]. However, an accumulation of unfolded proteins during severe ER stress is sometimes unable to be resolved by the UPR, as characterized in the Akita mouse which contains a mutation in the proinsulin 2 gene that disrupts insulin folding, retains it within the ER, activates UPR, yet still eventually leads to $\beta$-cell death $[196,197]$. Moreover, ROS have been suggested in supporting the UPR towards a more proapoptotic than proadaptive level [198], further illustrating the importance of regulating oxidative stress to maintain $\beta$-cell survival. Although the UPR paradoxically utilizes an oxidative environment within the ER to correctly fold proteins (i.e., disulfide bond formation), sustained oxidative stress can perpetuate the UPR to a level that promotes apoptosis $[198,199]$. Additionally, the abundance of ROS present during continued unadapted ER stress can trigger apoptosis in neighboring cells as well. This is especially critical in islet $\beta$-cells, where their ability to handle oxidative stress is already reduced because of low levels of antioxidants [24, 82-84]. More pertinent is when unresolved ER stress leads to dying $\beta$-cells containing the misfolded proteins. These cells can be taken up by resident pancreatic APCs and presented to autoreactive $\mathrm{T}$ cells within the pancreatic lymph nodes. This type of event may stimulate the reactivity of T cells to formerly tolerated "neo-autoantigens," which can ultimately promote more $\beta$-cell destruction and eventual development of autoimmune diabetes $[200,201]$. A study conducted by Malhotra, et al. shows that antioxidant treatment of $\mathrm{CHO}$ cells results in not only decreased oxidative stress, but also decreased misfolded proteins, reduced activation of the UPR, and enhanced secretion of proteins [188]. Thus, it appears that a temporal or redox balance is essential for optimal $\beta$ cell function. In situations where the $\beta$-cell may experience environmental stressors that lead to disruption of the ERmachinery, the results may set in motion both ER-stressinduced UPR and the expression of misfolded proteins in an oxidative environment, further providing an optimal milieu for driving autoreactive $\mathrm{T}$ cells to become activated. Therefore, redox modulation may serve yet another purpose: to help reduce ER stress and subsequently maintain $\beta$-cell viability.

Although the ability to predict susceptibility to type 1 diabetes is becoming increasingly accurate [202], and therefore, prophylactic treatment of patients with antioxidant therapeutics is not out of the realm of possibilities, currently a more feasible option for individuals with chronic hyperglycemia is to undergo islet transplantation. Islets, like any other transplantable organ, are in short supply; however, maintaining function and viability of transplanted islets is the major drawback of the procedure [161]. Not only are islets susceptible to immune rejection, but hypoxia during isolation and transplantation is the primary cause of $\beta$-cell death [203]. Because of their low resistance to ROS [24, 82$84], \beta$-cells are especially vulnerable to oxidative damage and ischemia-reperfusion injury [204, 205]. In order to combat this weakness, the application of antioxidants seems a suitable alternative, as they have shown promise in liver and kidney transplantations [206, 207]. Longer allograft survival times have been demonstrated with mouse islets soaked with hydroxyl-radical inhibitors prior to transplantation [208] and with multiple in vivo administrations of SOD and catalase prior to and after islet transplantation [209]. Likewise, transduction of islets with heme oxygenase- 1 or SOD2 genes was able to improve viability and insulin secretion in vitro [210] and elicit greater functionality upon transplantation in comparison to controls [211], respectively. Furthermore, we have also demonstrated benefit using the catalytic antioxidant approach, whereby adding CA during and after human islet isolation enhanced cell survival and function, allowing for normalization of STZinduced diabetic NOD.scid mice [212]. Additionally, CA is not only able to protect human islets from STZ cell damage, but can also protect murine islets from both antigenindependent innate-mediated inflammation and antigendependent T-cell-mediated allograft rejection [204]. Overall, unlike common antirejection drugs, which are outstanding at protecting against the adaptive immune response but fail to shield islets from ROS/inflammation [213, 214], our CA treatment is nontoxic to islets and can alleviate 


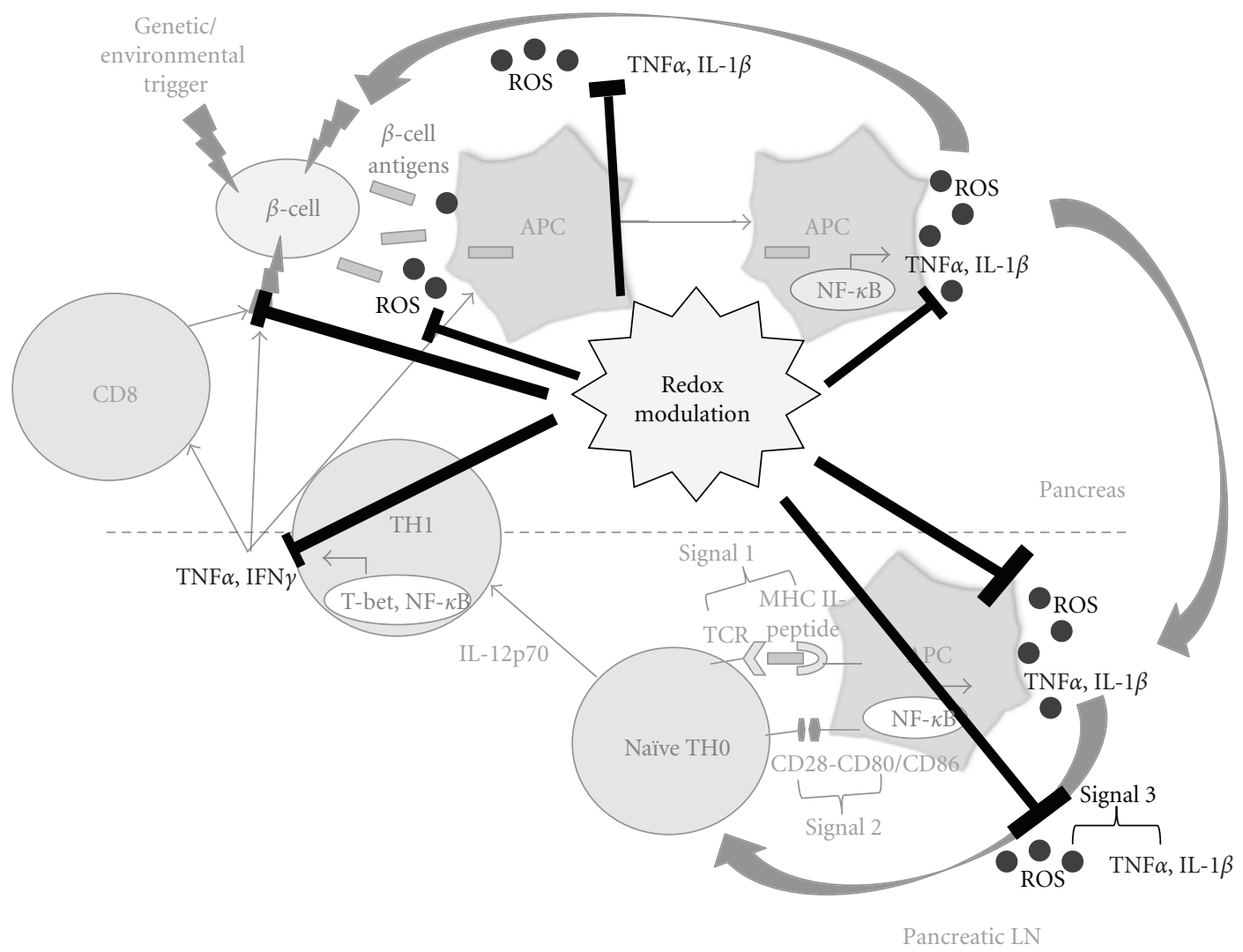

FIGURE 2: Role of redox modulation in controlling ROS-mediated beta cell destruction. Redox modulation has shown promise in blocking the production of ROS and its ability to activate APCs, resulting in diminished TH1 cell activation and effector function, which ultimately may help regulate beta-cell destruction.

both the alloimmune [204] and autoimmune responses $[25,37,53,185]$.

\section{Conclusion}

Although redox has been extensively studied in the context of both T1D and type 2 diabetes [85, 215], the plethora of literature discussed above shows the implications of ROS in all stages of autoimmune T1D, including the primary "trigger", the initiation of insulitis by the innate immune system, and the acquisition of T-cell-mediated autoreactivity. These studies open the door to novel ideas of redox modulation, such as targeting ROS-dependent immunological metalloproteases $[43,44,49]$ or disrupting the autoreactive T-cell pool, as described [37, 120, 185]. Moreover, a study evaluating self-antigen-primed $\mathrm{T}$ cells demonstrates how NO is able to reduce FOXP3 expression and subsequently decrease Tregs in autoimmune disorders [216], illustrating how intricate and vast the role of redox is in the immune response and where future studies may focus. In addition to effects on the target organ(s) and the immune system, autoimmunity also gives rise to systemic problems, and in the context of diabetes, ROS have been characterized as crucial elements promoting hyperglycemiainduced diabetic complications, especially those involving the vasculature $[6,217]$. One important study conducted by Ling et al. provided evidence of oxidative stress-mediated vascular complications in prediabetic NOD mice [218], which exemplifies the importance of ROS in not only exacerbation of disease, but also on initiation of T1D and nonhyperglycemic associated pathologies. Furthermore, utilizing antioxidants, such as Vitamin E, cannot only assuage vascular activation [219], but can also grant protection from the loss of secondary target organ function, such as the kidneys [220]. Therefore, oxidative stress affects every aspect of T1D and the benefit of redox modulation may be more important than once thought. Optimal treatments may have to incorporate antioxidants with anti-inflammatory agents, such as inhibitors of NF- $\kappa$ B activation, and must also take into consideration the limitations associated with utilization of intact enzyme/protein therapies, including bioavailability, immunogenicity-limited cellular accessibility, and cost of production. However, with the advent of newer nonpeptidyl small compounds, alleviating oxidative stress through antioxidant therapy appears to be a plausible druggable target. This therapy should restore balance between oxidation and reduction, leading to resolution of inflammation, thus reducing the autoimmune destruction of the islet $\beta$-cells. 


\section{References}

[1] J. M. McCord, "The evolution of free radicals and oxidative stress," American Journal of Medicine, vol. 108, no. 8, pp. 652$659,2000$.

[2] P. Rich, "Chemiosmotic coupling: the cost of living," Nature, vol. 421, no. 6923, p. 583, 2003.

[3] A. Boveris, N. Oshino, and B. Chance, "The cellular production of hydrogen peroxide," Biochemical Journal, vol. 128, no. 3, pp. 617-630, 1972.

[4] J. F. Turrens, "Superoxide production by the mitochondrial respiratory chain," Bioscience Reports, vol. 17, no. 1, pp. 3-8, 1997.

[5] F. B. Johnson, D. A. Sinclair, and L. Guarente, "Molecular biology of aging," Cell, vol. 96, no. 2, pp. 291-302, 1999.

[6] J. Limón-Pacheco and M. E. Gonsebatt, "The role of antioxidants and antioxidant-related enzymes in protective responses to environmentally induced oxidative stress," Mutation Research, vol. 674, no. 1-2, pp. 137-147, 2009.

[7] J. Chandra, A. Samali, and S. Orrenius, "Triggering and modulation of apoptosis by oxidative stress," Free Radical Biology and Medicine, vol. 29, no. 3-4, pp. 323-333, 2000.

[8] D. Harman, "The aging process," Proceedings of the National Academy of Sciences of the United States of America, vol. 78, no. 11, pp. 7124-7128, 1981.

[9] T. Finkel and N. J. Holbrook, "Oxidants, oxidative stress and the biology of ageing," Nature, vol. 408, no. 6809, pp. 239$247,2000$.

[10] A. Mitsui, J. Hamuro, H. Nakamura et al., "Overexpression of human thioredoxin in transgenic mice controls oxidative stress and life span," Antioxidants and Redox Signaling, vol. 4, no. 4, pp. 693-696, 2002.

[11] S. E. Schriner, N. J. Linford, G. M. Martin et al., "Medecine: extension of murine life span by overexpression of catalase targeted to mitochondria," Science, vol. 308, no. 5730, pp. 1909-1911, 2005.

[12] B. Halliwell, "Antioxidants in human health and disease," Annual Review of Nutrition, vol. 16, pp. 33-50, 1996.

[13] J. E. Klaunig, Y. Xu, J. S. Isenberg et al., "The role of oxidative stress in chemical carcinogenesis," Environmental Health Perspectives, vol. 106, no. 1, pp. 289-295, 1998.

[14] L. W. Oberley and G. R. Buettner, "Role of superoxide dismutase in cancer: a review," Cancer Research, vol. 39, no. 4, pp. 1141-1149, 1979.

[15] S. Toyokuni, "Persistent oxidative stress in cancer," FEBS Letters, vol. 358, no. 1, pp. 1-3, 1995.

[16] S. Bashir, G. Harris, M. A. Denman, D. R. Blake, and P. G. Winyard, "Oxidative DNA damage and cellular sensitivity to oxidative stress in human autoimmune diseases," Annals of the Rheumatic Diseases, vol. 52, no. 9, pp. 659-666, 1993.

[17] S. Jaswal, H. C. Mehta, A. K. Sood, and J. Kaur, "Antioxidant status in rheumatoid arthritis and role of antioxidant therapy," Clinica Chimica Acta, vol. 338, no. 1-2, pp. 123-129, 2003.

[18] D. A. Butterfield and C. M. Lauderback, "Lipid peroxidation and protein oxidation in Alzheimer's disease brain: potential causes and consequences involving amyloid $\beta$-peptideassociated free radical oxidative stress," Free Radical Biology and Medicine, vol. 32, no. 11, pp. 1050-1060, 2002.

[19] P. Jenner and C. W. Olanow, "Oxidative stress and the pathogenesis of Parkinson's disease," Neurology, vol. 47, no. 6, pp. S161-S170, 1996.
[20] I. I. Kruman, W. A. Pedersen, J. E. Springer, and M. P. Mattson, "ALS-linked Cu/Zn-SOD mutation increases vulnerability of motor neurons to excitotoxicity by a mechanism involving increased oxidative stress and perturbed calcium homeostasis," Experimental Neurology, vol. 160, no. 1, pp. 2839, 1999.

[21] M. A. Smith, P. L. Richey Harris, L. M. Sayre, J. S. Beckman, and G. Perry, "Widespread peroxynitrite-mediated damage in Alzheimer's disease," Journal of Neuroscience, vol. 17, no. 8, pp. 2653-2657, 1997.

[22] I. Rahman, S. K. Biswas, and A. Kode, "Oxidant and antioxidant balance in the airways and airway diseases," European Journal of Pharmacology, vol. 533, no. 1-3, pp. 222239, 2006.

[23] J. Chen, A. M. Gusdon, T. C. Thayer, and C. E. Mathews, "Role of increased ROS dissipation in prevention of T1D: lessons from the ALR mouse," Annals of the New York Academy of Sciences, vol. 1150, pp. 157-166, 2008.

[24] S. Lenzen, “Oxidative stress: the vulnerable $\beta$-cell," Biochemical Society Transactions, vol. 36, no. 3, pp. 343-347, 2008.

[25] J. D. Piganelli, S. C. Flores, C. Cruz et al., "A metalloporphyrin-based superoxide dismutase mimic inhibits adoptive transfer of autoimmune diabetes by a diabetogenic T-cell clone," Diabetes, vol. 51, no. 2, pp. 347-355, 2002.

[26] W. I. Sivitz and M. A. Yorek, "Mitochondrial dysfunction in diabetes: from molecular mechanisms to functional significance and therapeutic opportunities," Antioxidants and Redox Signaling, vol. 12, no. 4, pp. 537-577, 2010.

[27] B. M. Babior, R. S. Kipnes, and J. T. Curnutte, "Biological defense mechanisms. The production by leukocytes of superoxide, a potential bactericidal agent," Journal of Clinical Investigation, vol. 52, no. 3, pp. 741-744, 1973.

[28] S. H. Jackson, S. Devadas, J. Kwon, L. A. Pinto, and M. S. Williams, "T cells express a phagocyte-type NADPH oxidase that is activated after T cell receptor stimulation," Nature Immunology, vol. 5, no. 8, pp. 818-827, 2004.

[29] Y. A. Suh, R. S. Arnold, B. Lassegue et al., "Cell transformation by the superoxide-generating oxidase Mox1," Nature, vol. 401, no. 6748, pp. 79-82, 1999.

[30] J. D. Lambeth, "NOX enzymes and the biology of reactive oxygen," Nature Reviews Immunology, vol. 4, no. 3, pp. 181189, 2004.

[31] J. M. McCord, "Oxygen-derived radicals: a link between reperfusion injury and inflammation," Federation Proceedings, vol. 46, no. 7, pp. 2402-2406, 1987.

[32] W. F. Petrone, D. K. English, K. Wong, and J. M. McCord, "Free radicals and inflammation: superoxide-dependent activation of a neutrophil chemotactic factor in plasma," Proceedings of the National Academy of Sciences of the United States of America, vol. 77, no. 2, pp. 1159-1163, 1980.

[33] R. S. Arnold, J. Shi, E. Murad et al., "Hydrogen peroxide mediates the cell growth and transformation caused by the mitogenic oxidase Nox1," Proceedings of the National Academy of Sciences of the United States of America, vol. 98, no. 10 , pp. 5550-5555, 2001.

[34] G. A. C. Murrell, M. J. O. Francis, and L. Bromley, "Modulation of fibroblast proliferation by oxygen free radicals," Biochemical Journal, vol. 265, no. 3, pp. 659-665, 1990.

[35] J. L. Arbiser, J. Petros, R. Klafter et al., "Reactive oxygen generated by Nox1 triggers the angiogenic switch," Proceedings of the National Academy of Sciences of the United States of America, vol. 99, no. 2, pp. 715-720, 2002. 
[36] S. S. Brar, T. P. Kennedy, A. B. Sturrock et al., "An NAD(P)H oxidase regulates growth and transcription in melanoma cells," American Journal of Physiology, vol. 282, no. 6, pp. C1212-C1224, 2002.

[37] H. M. Tse, M. J. Milton, S. Schreiner, J. L. Profozich, M. Trucco, and J. D. Piganelli, "Disruption of innate-mediated proinflammatory cytokine and reactive oxygen species third signal leads to antigen-specific hyporesponsiveness," Journal of Immunology, vol. 178, no. 2, pp. 908-917, 2007.

[38] A. Saccani, S. Saccani, S. Orlando et al., "Redox regulation of chemokine receptor expression," Proceedings of the National Academy of Sciences of the United States of America, vol. 97, no. 6, pp. 2761-2766, 2000.

[39] M. Ushio-Fukai, "VEGF signaling through NADPH oxidasederived ROS," Antioxidants and Redox Signaling, vol. 9, no. 6, pp. 731-739, 2007.

[40] S. G. Rhee, S. W. Kang, W. Jeong, T. S. Chang, K. S. Yang, and H. A. Woo, "Intracellular messenger function of hydrogen peroxide and its regulation by peroxiredoxins," Current Opinion in Cell Biology, vol. 17, no. 2, pp. 183-189, 2005.

[41] S. G. Rhee, " $\mathrm{H}_{2} \mathrm{O}_{2}$, a necessary evil for cell signaling," Science, vol. 312, no. 5782, pp. 1882-1883, 2006.

[42] R. L. Whisler, M. A. Goyette, I. S. Grants, and Y. G. Newhouse, "Sublethal levels of oxidant stress stimulate multiple serine/threonine kinases and suppress protein phosphatases in Jurkat T cells," Archives of Biochemistry and Biophysics, vol. 319, no. 1, pp. 23-35, 1995.

[43] K. K. Nelson and J. A. Melendez, "Mitochondrial redox control of matrix metalloproteinases," Free Radical Biology and Medicine, vol. 37, no. 6, pp. 768-784, 2004.

[44] Y. Wang, A. H. Herrera, Y. Li, K. K. Belani, and B. Walcheck, "Regulation of mature ADAM17 by redox agents for Lselectin shedding," Journal of Immunology, vol. 182, no. 4, pp. 2449-2457, 2009.

[45] S. C. You, Y. O. Sun, and Z. Zhu, "Tyrosine phosphatase SHP-1 in oxidative stress and development of allergic airway inflammation," American Journal of Respiratory Cell and Molecular Biology, vol. 39, no. 4, pp. 412-419, 2008.

[46] J. M. Cunnick, J. F. Dorsey, L. Mei, and J. Wu, "Reversible regulation of SHP-1 tyrosine phosphatase activity by oxidation," Biochemistry and Molecular Biology International, vol. 45, no. 5, pp. 887-894, 1998.

[47] K. Lee and W. J. Esselman, "Inhibition of PTPs by $\mathrm{H}_{2} \mathrm{O}_{2}$ regulates the activation of distinct MAPK pathways," Free Radical Biology and Medicine, vol. 33, no. 8, pp. 1121-1132, 2002.

[48] M. Reth, "Hydrogen peroxide as second messenger in lymphocyte activation," Nature Immunology, vol. 3, no. 12, pp. 1129-1134, 2002.

[49] M. Pietri, B. Schneider, S. Mouillet-Richard et al., "Reactive oxygen species-dependent TNF- $\alpha$ converting enzyme activation through stimulation of 5-HT and $\alpha$ autoreceptors in neuronal cells," FASEB Journal, vol. 19, no. 9, pp. 1078-1087, 2005.

[50] M. Meyer, H. L. Pahl, and P. A. Baeuerle, "Regulation of the transcription factors NF- $\kappa \mathrm{B}$ and $\mathrm{AP}-1$ by redox changes," Chemico-Biological Interactions, vol. 91, no. 2-3, pp. 91-100, 1994.

[51] R. Schreck, P. Rieber, and P. A. Baeuerle, "Reactive oxygen intermediates as apparently widely used messengers in the activation of the NF- $\kappa \mathrm{B}$ transcription factor and HIV-1," EMBO Journal, vol. 10, no. 8, pp. 2247-2258, 1991.
[52] Y. J. Suzuki, H. J. Forman, and A. Sevanian, "Oxidants as stimulators of signal transduction," Free Radical Biology and Medicine, vol. 22, no. 1-2, pp. 269-285, 1996.

[53] H. M. Tse, M. J. Milton, and J. D. Piganelli, "Mechanistic analysis of the immunomodulatory effects of a catalytic antioxidant on antigen-presenting cells: implication for their use in targeting oxidation-reduction reactions in innate immunity," Free Radical Biology and Medicine, vol. 36, no. 2, pp. 233-247, 2004.

[54] H. S. Park, H. Y. Jung, E. Y. Park, J. Kim, W. J. Lee, and Y. S. Bae, "Cutting edge: direct interaction of TLR4 with $\mathrm{NAD}(\mathrm{P}) \mathrm{H}$ oxidase 4 isozyme is essential for lipopolysaccharide-induced production of reactive oxygen species and activation of NF- $\kappa \mathrm{B}$," Journal of Immunology, vol. 173, no. 6, pp. 3589-3593, 2004.

[55] J. D. Crapo, "Oxidative stress as an initiator of cytokine release and cell damage," European Respiratory Journal, Supplement, vol. 44, pp. 4s-6s, 2003.

[56] E. Ho and T. M. Bray, "Antioxidants, NF $\kappa$ B activation, and diabetogenesis," Proceedings of the Society for Experimental Biology and Medicine, vol. 222, no. 3, pp. 205-213, 1999.

[57] J. M. Curtsinger, C. S. Schmidt, A. Mondino et al., "Inflammatory cytokines provide a third signal for activation of naive CD4+ and CD8+ T cells," Journal of Immunology, vol. 162, no. 6, pp. 3256-3262, 1999.

[58] H. M. Lander, "An essential role for free radicals and derived species in signal transduction," FASEB Journal, vol. 11, no. 2, pp. 118-124, 1997.

[59] C. F. Nathan and R. K. Root, "Hydrogen peroxide release from mouse peritoneal macrophages. Dependence on sequential activation and triggering," Journal of Experimental Medicine, vol. 146, no. 6, pp. 1648-1662, 1977.

[60] Y. Zhang, J. Wienands, C. Zürn, and M. Reth, "Induction of the antigen receptor expression on B lymphocytes results in rapid competence for signaling of SLP-65 and Syk," EMBO Journal, vol. 17, no. 24, pp. 7304-7310, 1998.

[61] S. Devadas, L. Zaritskaya, S. G. Rhee, L. Oberley, and M. S. Williams, "Discrete generation of superoxide and hydrogen peroxide by $\mathrm{T}$ cell receptor stimulation: selective regulation of mitogen-activated protein kinase activation and Fas ligand expression," Journal of Experimental Medicine, vol. 195, no. 1, pp. 59-70, 2002.

[62] M. Los, W. Dröge, K. Stricker, P. A. Baeuerle, and K. SchulzeOsthoff, "Hydrogen peroxide as a potent activator of $\mathrm{T}$ lymphocyte functions," European Journal of Immunology, vol. 25, no. 1, pp. 159-165, 1995.

[63] M. Karin, "The NF- $\kappa$ B activation pathway: its regulation and role in inflammation and cell survival," Cancer Journal from Scientific American, vol. 4, no. 1, pp. S92-S99, 1998.

[64] G. Gloire, S. Legrand-Poels, and J. Piette, "NF- $\kappa$ B activation by reactive oxygen species: fifteen years later," Biochemical Pharmacology, vol. 72, no. 11, pp. 1493-1505, 2006.

[65] R. Bottino, A. N. Balamurugan, H. Tse et al., "Response of human islets to isolation stress and the effect of antioxidant treatment," Diabetes, vol. 53, no. 10, pp. 2559-2568, 2004.

[66] A. Rabinovitch, "Free radicals as mediators of pancreatic islet $\beta$-cell injury in autoimmune diabetes," Journal of Laboratory and Clinical Medicine, vol. 119, no. 5, pp. 455-456, 1992.

[67] P. O. T. Tran, S. M. Parker, E. LeRoy et al., "Adenoviral overexpression of the glutamylcysteine ligase catalytic subunit protects pancreatic islets against oxidative stress," Journal of Biological Chemistry, vol. 279, no. 52, pp. 53988-53993, 2004. 
[68] I. C. West, "Radicals and oxidative stress in diabetes," Diabetic Medicine, vol. 17, no. 3, pp. 171-180, 2000.

[69] E. Horio, M. Fukuda, H. Katoh et al., "Reactive oxygen intermediates in autoimmune islet cell destruction of the NOD mouse induced by peritoneal exudate cells (rich in macrophages) but not T cells," Diabetologia, vol. 37, no. 1, pp. 22-31, 1994.

[70] J. Nerup, T. Mandrup-Poulsen, J. Molvig, S. Helqvist, L. Wogensen, and J. Egeberg, "Mechanisms of pancreatic $\beta$ cell destruction in type I diabetes," Diabetes Care, vol. 11, supplement 1, pp. 16-23, 1988.

[71] W. L. Suarez-Pinzon, C. Szabó, and A. Rabinovitch, "Development of autoimmune diabetes in NOD mice is associated with the formation of peroxynitrite in pancreatic islet $\beta$ cells," Diabetes, vol. 46, no. 5, pp. 907-911, 1997.

[72] S. R. J. Maxwell, H. Thomason, D. Sandler et al., "Antioxidant status in patients with uncomplicated insulin-dependent and non-insulin-dependent diabetes mellitus," European Journal of Clinical Investigation, vol. 27, no. 6, pp. 484-490, 1997.

[73] B. Ročić, M. Vučić, J. Knežević-Ćuća et al., "Total plasma antioxidants in first-degree relatives of patients with insulindependent diabetes," Experimental and Clinical Endocrinology and Diabetes, vol. 105, no. 4, pp. 213-217, 1997.

[74] S. A. Santini, G. Marra, B. Giardina et al., "Defective plasma antioxidant defenses and enhanced susceptibility to lipid peroxidation in uncomplicated IDDM," Diabetes, vol. 46, no. 11, pp. 1853-1858, 1997.

[75] D. R. Gamble and K. W. Taylor, "Seasonal incidence of diabetes mellitus," British medical journal, vol. 3, no. 671, pp. 631-633, 1969.

[76] D. R. Gamble, K. W. Taylor, and H. Cumming, "Coxsackie viruses and diabetes mellitus," British Medical Journal, vol. 4, no. 5887 , pp. 260-262, 1973.

[77] T. J. Coleman, D. R. Gamble, and K. W. Taylor, "Diabetes in mice after Coxsackie B 4 virus infection," British medical journal, vol. 3, no. 5870, pp. 25-27, 1973.

[78] J. W. Yoon, T. Onodera, and A. L. Notkins, "Virusinduced diabetes mellitus. XV. Beta cell damage and insulindependent hyperglycemia in mice infected with Coxsackie virus B4," Journal of Experimental Medicine, vol. 148, no. 4, pp. 1068-1080, 1978.

[79] A. K. Berg, O. Korsgren, and G. Frisk, "Induction of the chemokine interferon-gamma-inducible protein-10 in human pancreatic islets during enterovirus infection," Diabetologia, vol. 49, no. 11, pp. 2697-2703, 2006.

[80] B. Xie, J. F. Zhou, Q. Lu, C. J. Li, and P. Chen, "Oxidative stress in patients with acute coxsackie virus myocarditis," Biomedical and Environmental Sciences, vol. 15, no. 1, pp. 4857, 2002.

[81] E. Peterhans, M. Grob, T. Bürge, and R. Zanoni, "Virusinduced formation of reactive oxygen intermediates in phagocytic cells," Free Radical Research Communications, vol. 3, no. 1-5, pp. 39-46, 1987.

[82] S. Lenzen, J. Drinkgern, and M. Tiedge, "Low antioxidant enzyme gene expression in pancreatic islets compared with various other mouse tissues," Free Radical Biology and Medicine, vol. 20, no. 3, pp. 463-466, 1996.

[83] M. Tiedge, S. Lortz, J. Drinkgern, and S. Lenzen, "Relation between antioxidant enzyme gene expression and antioxidative defense status of insulin-producing cells," Diabetes, vol. 46, no. 11, pp. 1733-1742, 1997.
[84] K. Grankvist, S. L. Marklund, and I. B. Taljedal, "CuZnsuperoxide dismutase, Mn-superoxide dismutase, catalase and glutathione peroxidase in pancreatic islets and other tissues in the mouse," Biochemical Journal, vol. 199, no. 2, pp. 393-398, 1981.

[85] P. Newsholme, E. P. Haber, S. M. Hirabara et al., "Diabetes associated cell stress and dysfunction: role of mitochondrial and non-mitochondrial ROS production and activity," Journal of Physiology, vol. 583, no. 1, pp. 9-24, 2007.

[86] P. Maechler, L. Jornot, and C. B. Wollheim, "Hydrogen peroxide alters mitochondrial activation and insulin secretion in pancreatic beta cells," Journal of Biological Chemistry, vol. 274, no. 39, pp. 27905-27913, 1999.

[87] T. Nishikawa, D. Edelstein, X. L. Du et al., "Normalizing mitochondrial superoxide production blocks three pathways of hyperglycaemic damage," Nature, vol. 404, no. 6779, pp. 787-790, 2000.

[88] N. Welsh and C. Hellerstrom, "In vitro restoration of insulin production in islets from adult rats treated neonatally with streptozotocin," Endocrinology, vol. 126, no. 4, pp. 18421848, 1990.

[89] T. Szkudelski, "The mechanism of alloxan and streptozotocin action in B cells of the rat pancreas," Physiological Research, vol. 50, no. 6, pp. 537-546, 2001.

[90] D. C. Weaver, M. L. McDaniel, and P. E. Lacy, "Alloxan uptake by isolated rat islets of langerhans," Endocrinology, vol. 102, no. 6, pp. 1847-1855, 1978.

[91] R. Munday, "Dialuric acid autoxidation: effects of transition metals on the reaction rate and on the generation of "active oxygen” species," Biochemical Pharmacology, vol. 37, no. 3, pp. 409-413, 1988.

[92] N. Takasu, I. Komiya, T. Asawa, Y. Nagasawa, and T. Yamada, "Streptozocin- and alloxan-induced $\mathrm{H}_{2} \mathrm{O}_{2}$ generation and DNA fragmentation in pancreatic islets: $\mathrm{HO}$ as mediator for DNA fragmentation," Diabetes, vol. 40, no. 9, pp. 1141-1145, 1991.

[93] T. Ino, Y. Kawamoto, K. Sato et al., "Selection of mouse strains showing high and low incidences of alloxan-induced diabetes," Jikken dobutsu. Experimental animals, vol. 40, no. 1, pp. 61-67, 1991.

[94] C. E. Mathews, R. T. Graser, A. Savinov, D. V. Serreze, and E. H. Leiter, "Unusual resistance of ALR/Lt mouse $\beta$ cells to autoimmune destruction: role for $\beta$ cell-expressed resistance determinants," Proceedings of the National Academy of Sciences of the United States of America, vol. 98, no. 1, pp. 235240, 2001.

[95] S. Sandler and I. Swenne, "Streptozotocin, but not alloxan, induces DNA repair synthesis in mouse pancreatic islets in vitro," Diabetologia, vol. 25, no. 5, pp. 444-447, 1983.

[96] M. Nukatsuka, H. Sakurai, Y. Yoshimura, M. Nishida, and J. Kawada, "Enhancement by streptozotocin of $\mathrm{O}_{2}$ radical generation by the xanthine oxidase system of pancreatic $\beta$ cells," FEBS Letters, vol. 239, no. 2, pp. 295-298, 1988.

[97] K. D. Kroncke, K. Fehsel, A. Sommer, M. L. Rodriguez, and V. Kolb-Bachofen, "Nitric oxide generation during cellular metabolization of the diabetogenic N-methyl-N-nitrosourea streptozotozin contributes to islet cell DNA damage," Biological Chemistry Hoppe-Seyler, vol. 376, no. 3, pp. 179185, 1995.

[98] D. Morgan, H. R. Oliveira-Emilio, D. Keane et al., "Glucose, palmitate and pro-inflammatory cytokines modulate production and activity of a phagocyte-like NADPH oxidase in rat pancreatic islets and a clonal beta cell line," Diabetologia, vol. 50, no. 2, pp. 359-369, 2007. 
[99] H. R. Oliveira, R. Verlengia, C. R. O. Carvalho, L. R. G. Britto, R. Curi, and A. R. Carpinelli, "Pancreatic $\beta$-cells express phagocyte-like NAD $(\mathrm{P}) \mathrm{H}$ oxidase," Diabetes, vol. 52, no. 6, pp. 1457-1463, 2003.

[100] R. Gyurko, C. C. Siqueira, N. Caldon, LI. Gao, A. Kantarci, and T. E. Van Dyke, "Chronic hyperglycemia predisposes to exaggerated inflammatory response and leukocyte dysfunction in Akita mice," Journal of Immunology, vol. 177, no. 10, pp. 7250-7256, 2006.

[101] L. A. O’Reilly, P. R. Hutchings, P. R. Crocker et al., "Characterization of pancreatic islet cell infiltrates in NOD mice: effect of cell transfer and transgene expression," European Journal of Immunology, vol. 21, no. 5, pp. 1171-1180, 1991.

[102] K. Lee, K. Amano, and J. Yoon, "Evidence for initial involvement of macrophage in development of insulitis in NOD mice," Diabetes, vol. 37, no. 7, pp. 989-991, 1988.

[103] J. Nerup, T. Mandrup-Poulsen, S. Helqvist et al., "On the pathogenesis of IDDM," Diabetologia, vol. 37, supplement 2, pp. S82-S89, 1994.

[104] J. L. Tiwari and P. I. Terasaki, "HLA-DR and disease associations," Progress in Clinical and Biological Research, vol. 58, pp. 151-163, 1981.

[105] F. J.T. Staal, M. Roederer, L. A. Herzenberg, and L. A. Herzenberg, "Intracellular thiols regulate activation of nuclear factor $\kappa \mathrm{B}$ and transcription of human immunodeficiency virus," Proceedings of the National Academy of Sciences of the United States of America, vol. 87, no. 24, pp. 9943-9947, 1990.

[106] W. Held, H. R. MacDonald, I. L. Weissman, M. W. Hess, and C. Mueller, "Genes encoding tumor necrosis factor alpha and granzyme A are expressed during development of autoimmune diabetes," Proceedings of the National Academy of Sciences of the United States of America, vol. 87, pp. 22392243, 1990.

[107] Z. Jiang and B. A. Woda, "Cytokine gene expression in the islets of the diabetic Biobreeding/Worcester rat," Journal of Immunology, vol. 146, no. 9, pp. 2990-2994, 1991.

[108] T. Mandrup-Poulsen, G. A. Spinas, S. J. Prowse et al., "Islet cytotoxicity of interleukin 1 . Influence of culture conditions and islet donor characteristics," Diabetes, vol. 36, no. 5, pp. 641-647, 1987.

[109] T. Mandrup-Poulsen, J. Egeberg, and J. Nerup, "Ultrastructural studies of time-course and cellular specificity of interleukin-1 mediated islet cytotoxicity," Acta Pathologica Microbiologica et Immunologica Scandinavica C, vol. 95, no. 2, pp. 55-63, 1987.

[110] C. Southern, D. Schulster, and I. C. Green, "Inhibition of insulin secretion by interleukin- $1 \beta$ and tumour necrosis factor- $\alpha$ via an L-arginine-dependent nitric oxide generating mechanism," FEBS Letters, vol. 276, no. 1-2, pp. 42-44, 1990.

[111] M. Arnush, M. R. Heitmeier, A. L. Scarim, M. H. Marino, P. T. Manning, and J. A. Corbett, "IL-1 produced and released endogenously within human islets inhibits $\beta$ cell function," Journal of Clinical Investigation, vol. 102, no. 3, pp. 516-526, 1998.

[112] T. Mandrup-Poulsen, K. Bendtzen, C. A. Dinarello, and J. Nerup, "Human tumor necrosis factor potentiates human interleukin 1-mediated rat pancreatic $\beta$-cell cytotoxicity," Journal of Immunology, vol. 139, no. 12, pp. 4077-4082, 1987.

[113] I. L. Campbell, L. Oxbrow, J. West, and L. C. Harrison, "Regulation of MHC protein expression in pancreatic betacells by interferon-gamma and tumor necrosis factor-alpha," Molecular Endocrinology, vol. 2, pp. 101-107, 1988.
[114] H. E. Thomas and T. W. H. Kay, "Beta cell destruction in the development of autoimmune diabetes in the non-obese diabetic (NOD) mouse," Diabetes/Metabolism Research and Reviews, vol. 16, no. 4, pp. 251-261, 2000.

[115] M. Torres and H. J. Forman, "Redox signaling and the MAP kinase pathways," BioFactors, vol. 17, no. 1-4, pp. 287-296, 2003.

[116] Y. Murata, T. Shimamura, and J. Hamuro, "The polarization of Th1/Th2 balance is dependent on the intracellular thiol redox status of macrophages due to the distinctive cytokine production," International Immunology, vol. 14, no. 2, pp. 201-212, 2002.

[117] C. A. Dinarello, J. G. Cannon, and J. W. Mier, "Multiple biological activities of human recombinant interleukin 1," Journal of Clinical Investigation, vol. 77, no. 6, pp. 1734-1739, 1986.

[118] E. A. Green, E. E. Eynon, and R. A. Flaveirti, "Local expression of TNF $\alpha$ in neonatal NOD mice promotes diabetes by enhancing presentation of islet antigens," Immunity, vol. 9, no. 5, pp. 733-743, 1998.

[119] C. Huang, J. Li, M. Costa et al., "Hydrogen peroxide mediates activation of nuclear factor of activated T cells (NFAT) by nickel subsulfide," Cancer Research, vol. 61, no. 22, pp. 8051$8057,2001$.

[120] H. M. Tse, T. C. Thayer, C. Steele et al., "NADPH oxidase deficiency regulates Th lineage commitment and modulates autoimmunity," Journal of Immunology, vol. 185, no. 9, pp. 5247-5258, 2010.

[121] M. L. Schmitz, S. Bacher, and O. Dienz, "NF- $\kappa$ B activation pathways induced by T cell costimulation," FASEB Journal, vol. 17, no. 15, pp. 2187-2193, 2003.

[122] Y.-H. Chung, H.-S. Jun, Y. Kang et al., "Role of macrophages and macrophage-derived cytokines in the pathogenesis of Kilham rat virus-induced autoimmune diabetes in diabetesresistant BioBreeding rats," Journal of Immunology, vol. 159, no. 1, pp. 466-471, 1997.

[123] A. Holz, B. Adrian, B. Coon, T. Wolfe, M. J. Grusby, and M. G. Von Herrath, "Disruption of the STAT4 signaling pathway protects from autoimmune diabetes while retaining antiviral immune competence," Journal of Immunology, vol. 163, no. 10, pp. 5374-5382, 1999.

[124] N. G. Jacobson, S. J. Szabo, R. M. Weber-Nordt et al., "Interleukin 12 signaling in T helper type 1 (Th1) cells involves tyrosine phosphorylation of signal transducer and activator of transcription (Stat)3 and Stat4," Journal of Experimental Medicine, vol. 181, no. 5, pp. 1755-1762, 1995.

[125] S. E. Macatonia, C.-S. Hsieh, K. M. Murphy, and A. O'Garra, "Dendritic cells and macrophages are required for Th1 development of CD4+ $\mathrm{t}$ cells from $\alpha \beta$ TCR transgenic mice: IL-12 substitution for macrophages to stimulate IFN- $\gamma$ production is IFN- $\gamma$-dependent," International Immunology, vol. 5, no. 9, pp. 1119-1128, 1993.

[126] N. Sarvetnick, J. Shizuru, D. Liggitt et al., "Loss of pancreatic islet tolerance induced by $\beta$-cell expression of interferon- $\gamma$," Nature, vol. 346, no. 6287, pp. 844-847, 1990.

[127] M. Debray-Sachs, C. Carnaud, C. Boitard et al., "Prevention of diabetes in NOD mice treated with antibody to murine IFN $\gamma$," Journal of Autoimmunity, vol. 4, no. 2, pp. 237-248, 1991.

[128] BO. Wang, I. André, A. Gonzalez et al., "Interferon- $\gamma$ impacts at multiple points during the progression of autoimmune diabetes," Proceedings of the National Academy of Sciences of the United States of America, vol. 94, no. 25, pp. 13844-13849, 1997. 
[129] M. Cnop, N. Welsh, J.-C. Jonas, A. Jörns, S. Lenzen, and D. L. Eizirik, "Mechanisms of pancreatic $\beta$-cell death in type 1 and type 2 diabetes: many differences, few similarities," Diabetes, vol. 54, supplement 2, pp. S97-S107, 2005.

[130] D. L. Eizirik, F. Moore, D. Flamez, and F. Ortis, "Use of a systems biology approach to understand pancreatic $\beta$-cell death in Type 1 diabetes," Biochemical Society Transactions, vol. 36, no. 3, pp. 321-327, 2008.

[131] F. Moore, N. Naamane, M. L. Colli et al., "STAT1 is a master regulator of pancreatic $\beta$-cell apoptosis and islet inflammation," Journal of Biological Chemistry, vol. 286, no. 2, pp. 929-941, 2011.

[132] L. A. Stephens, H. E. Thomas, L. Ming, M. G.R. Darwiche, L. Volodin, and T. W.H. Kay, "Tumor necrosis factor- $\alpha$ activated cell death pathways in NIT-1 insulinoma cells and primary pancreatic $\beta$ cells," Endocrinology, vol. 140, no. 7, pp. 3219-3227, 1999.

[133] W. H. Kim, J. W. Lee, B. Gao, and M. H. Jung, "Synergistic activation of JNK/SAPK induced by TNF- $\alpha$ and IFN- $\gamma$ : apoptosis of pancreatic $\beta$-cells via the p53 and ROS pathway," Cellular Signalling, vol. 17, no. 12, pp. 1516-1532, 2005.

[134] D. L. Eizirik and T. Mandrup-Poulsen, "A choice of deaththe signal-transduction of immune-mediated beta-cell apoptosis," Diabetologia, vol. 44, no. 12, pp. 2115-2133, 2001.

[135] M. O. Kurrer, S. V. Pakala, H. L. Hanson, and J. D. Katz, " $\beta$ cell apoptosis in T cell-mediated autoimmune diabetes," Proceedings of the National Academy of Sciences of the United States of America, vol. 94, no. 1, pp. 213-218, 1997.

[136] A. Suri and J. D. Katz, "Dissecting the role of CD4+ T cells autoimmune diabetes through the use of TCR transgenic mice," Immunological Reviews, vol. 169, pp. 55-65, 1999.

[137] T. P. DiLorenzo, R. T. Graser, T. Ono et al., "Major histocompatibility complex class I-restricted $\mathrm{T}$ cells are required for all but the end stages of diabetes development in nonobese diabetic mice and use a prevalent T cell receptor $\alpha$ chain gene rearrangement," Proceedings of the National Academy of Sciences of the United States of America, vol. 95, no. 21, pp. 12538-12543, 1998.

[138] A. Bendelac, C. Carnaud, C. Boitard, and J. F. Bach, "Syngeneic transfer of autoimmune diabetes from diabetic NOD mice to healthy neonates. Requirement for both L3T4+ and Lyt-2+ cells," Journal of Experimental Medicine, vol. 166, no. 4, pp. 823-832, 1987.

[139] S. W. Christianson, L. D. Shultz, and E. H. Leiter, "Adoptive transfer of diabetes into immunodeficient NOD-scid/scid mice: relative contributions of CD4+ and CD8+ T-cells from diabetic versus prediabetic NOD.NON-Thy-1 donors," Diabetes, vol. 42, no. 1, pp. 44-55, 1993.

[140] S. V. Pakala, M. Chivetta, C. B. Kelly, and J. D. Katz, "In autoimmune diabetes the transition from benign to pernicious insulitis requires an islet cell response to tumor necrosis factor $\alpha$," Journal of Experimental Medicine, vol. 189, no. 7, pp. 1053-1062, 1999.

[141] A. Amrani, J. Verdaguer, B. Anderson, T. Utsugi, S. Bou, and P. Santamaria, "Perforin-independent $\beta$-cell destruction by diabetogenic CD8+ T lymphocytes in transgenic nonobese diabetic mice," Journal of Clinical Investigation, vol. 103, no. 8, pp. 1201-1209, 1999.

[142] D. Kägi, B. Odermatt, P. Seiler, R. M. Zinkernagel, T. W. Mak, and H. Hengartner, "Reduced incidence and delayed onset of diabetes in perforin-deficient nonobese diabetic mice," Journal of Experimental Medicine, vol. 186, no. 7, pp. 989997, 1997.
[143] W. L. Suarez-Pinzon and A. Rabinovitch, "Approaches to type 1 diabetes prevention by intervention in cytokine immunoregulatory circuits," International Journal of Experimental Diabetes Research, vol. 2, no. 1, pp. 3-17, 2001.

[144] T. Mandrup-Poulsen, "The role of interleukin-1 in the pathogenesis of IDDM," Diabetologia, vol. 39, no. 9, pp. 1005-1029, 1996.

[145] X. G. Lei and M. Z. Vatamaniuk, "Two tales of antioxidant enzymes on beta cells and diabetes," Antioxid Redox Signal. In press.

[146] D. A. Lepore, T. A. Shinkel, N. Fisicaro et al., "Enhanced expression of glutathione peroxidase protects islet $\beta$ cells from hypoxia-reoxygenation," Xenotransplantation, vol. 11, no. 1, pp. 53-59, 2004.

[147] C. Moriscot, M. J. Richard, M. C. Favrot, and P. Y. Benhamou, "Protection of insulin-secreting INS-1 cells against oxidative stress through adenoviral-mediated glutathione peroxidase overexpression," Diabetes and Metabolism, vol. 29, pp. 145$151,2003$.

[148] S. Cuzzocrea, E. Mazzon, L. Dugo et al., "Protective effects of a new stable, highly active SOD mimetic, M40401 in splanchnic artery occlusion and reperfusion," British Journal of Pharmacology, vol. 132, no. 1, pp. 19-29, 2001.

[149] D. Salvemini, E. Mazzon, L. Dugo et al., "Pharmacological manipulation of the inflammatory cascade by the superoxide dismutase mimetic, M40403," British Journal of Pharmacology, vol. 132, no. 4, pp. 815-827, 2001.

[150] S. Lortz, M. Tiedge, T. Nachtwey, A. E. Karlsen, J. Nerup, and S. Lenzen, "Protection of insulin-producing RINm5F cells against cytokine-mediated toxicity through overexpression of antioxidant enzymes," Diabetes, vol. 49, no. 7, pp. 11231130, 2000.

[151] M. Sander and M. S. German, "The $\beta$ cell transcription factors and development of the pancreas," Journal of Molecular Medicine, vol. 75, no. 5, pp. 327-340, 1997.

[152] H. Kaneto, Y. Kajimoto, J. Miyagawa et al., "Beneficial effects of antioxidants in diabetes: possible protection of pancreatic $\beta$-cells against glucose toxicity," Diabetes, vol. 48, no. 12, pp. 2398-2406, 1999.

[153] D. Kawamori, Y. Kajimoto, H. Kaneto et al., "Oxidative stress induces nucleo-cytoplasmic translocation of pancreatic transcription factor Pdx-1 through activation of c-jun NH2terminal kinase," Diabetes, vol. 52, no. 12, pp. 2896-2904, 2003.

[154] M. J. Boucher, L. Selander, L. Carlsson, and H. Edlund, "Phosphorylation marks IPF1/PDX1 protein for degradation by glycogen synthase kinase 3-dependent mechanisms," Journal of Biological Chemistry, vol. 281, no. 10, pp. 63956403, 2006.

[155] X. D. Wang, M. Z. Vatamaniuk, S. K. Wang, C. A. Roneker, R. A. Simmons, and X. G. Lei, "Molecular mechanisms for hyperinsulinaemia induced by overproduction of seleniumdependent glutathione peroxidase-1 in mice," Diabetologia, vol. 51, no. 8, pp. 1515-1524, 2008.

[156] X. Li, H. Chen, and P. N. Epstein, "Metallothionein and catalase sensitize to diabetes in nonobese diabetic mice: reactive oxygen species may have a protective role in pancreatic $\beta$ cells," Diabetes, vol. 55, no. 6, pp. 1592-1604, 2006.

[157] P. Coyle, J. C. Philcox, L. C. Carey, and A. M. Rofe, "Metallothionein: the multipurpose protein," Cellular and Molecular Life Sciences, vol. 59, no. 4, pp. 627-647, 2002. 
[158] J. Sandström, L. M. Jonsson, H. Edlund, D. Holmberg, and S. L. Marklund, "Overexpression of extracellular-SOD in islets of nonobese diabetic mice and development of diabetes," Free Radical Biology and Medicine, vol. 33, no. 1, pp. 71-75, 2002.

[159] B. J. Goldstein, M. Kalyankar, and X. Wu, "Redox paradox: insulin action is facilitated by insulin-stimulated reactive oxygen species with multiple potential signaling targets," Diabetes, vol. 54, no. 2, pp. 311-321, 2005.

[160] M. Hotta, F. Tashiro, H. Ikegami et al., "Pancreatic $\beta$ cellspecific expression of thioredoxin, an antioxidative and antiapoptotic protein, prevents autoimmune and streptozotocininduced diabetes," Journal of Experimental Medicine, vol. 188, no. 8, pp. 1445-1451, 1998.

[161] B. O. Xu, J. T. Moritz, and P. N. Epstein, "Overexpression of catalase provides partial protection to transgenic mouse beta cells," Free Radical Biology and Medicine, vol. 27, no. 7-8, pp. 830-837, 1999.

[162] P. Y. Benhamou, C. Moriscot, M. J. Richard et al., "Adenovirus-mediated catalase gene transfer reduces oxidant stress in human, porcine and rat pancreatic islets," Diabetologia, vol. 41, no. 9, pp. 1093-1100, 1998.

[163] H. Chen, E. C. Carlson, L. Pellet, J. T. Moritz, and P. N. Epstein, "Overexpression of metallothionein in pancreatic $\beta$-cells reduces streptozotocin-induced DNA damage and diabetes," Diabetes, vol. 50, no. 9, pp. 2040-2046, 2001.

[164] S. H. Huang, C. H. Chu, J. C. Yu et al., "Transgenic expression of haem oxygenase-1 in pancreatic beta cells protects nonobese mice used as a model of diabetes from autoimmune destruction and prolongs graft survival following islet transplantation," Diabetologia, vol. 53, no. 11, pp. 2389-2400, 2010.

[165] H. M. Kubisch, J. Wang, T. M. Bray, and J. P. Phillips, "Targeted overexpression of $\mathrm{Cu} / \mathrm{Zn}$ superoxide dismutase protects pancreatic $\beta$-cells against oxidative stress," Diabetes, vol. 46, no. 10, pp. 1563-1566, 1997.

[166] C. E. Mathews and E. H. Leiter, "Constitutive differences in antioxidant defense status distinguish alloxan-resistant and alloxan-susceptible mice," Free Radical Biology and Medicine, vol. 27, no. 3-4, pp. 449-455, 1999.

[167] A. Rabinovitch, W. L. Suarez, and R. F. Power, "Lazaroid antioxidant reduces incidence of diabetes and insulitis in nonobese diabetic mice," Journal of Laboratory and Clinical Medicine, vol. 121, no. 4, pp. 603-607, 1993.

[168] P. Ohly, C. Dohle, J. Abel, J. Seissler, and H. Gleichmann, "Zinc sulphate induces metallothionein in pancreatic islets of mice and protects against diabetes induced by multiple low doses of streptozotocin," Diabetologia, vol. 43 , no. 8 , pp. 1020-1030, 2000.

[169] S. D. Stosic-Grujicic, D. M. Miljkovic, I. D. Cvetkovic, D. D. Maksimovic-Ivanic, and V. Trajkovic, "Immunosuppressive and anti-inflammatory action of antioxidants in rat autoimmune diabetes," Journal of Autoimmunity, vol. 22, no. 4, pp. 267-276, 2004.

[170] C. M. Hu, H. H. Lin, M. T. Chiang, PI. F. Chang, and L. Y. Chau, "Systemic expression of heme oxygenase-1 ameliorates type 1 diabetes in NOD mice," Diabetes, vol. 56, no. 5, pp. 1240-1247, 2007.

[171] C. E. Mathews, B. D. Dunn, M. O. Hannigan, C. K. Huang, and E. H. Leiter, "Genetic control of neutrophil superoxide production in diabetes-resistant ALR/Lt mice," Free Radical Biology and Medicine, vol. 32, no. 8, pp. 744-751, 2002.

[172] M. Matsushita, G. Yoshino, M. Iwai et al., "Protective effect of probucol on alloxan diabetes in rats," Diabetes Research and Clinical Practice, vol. 7, no. 4, pp. 313-316, 1989.
[173] A. L. Drash, W. A. Rudert, S. Borquaye, R. Wang, and I. Lieberman, "Effect of probucol on development of diabetes mellitus in BB rats," American Journal of Cardiology, vol. 62, no. 3, pp. 27B-30B, 1988.

[174] M. Fukuda, H. Ikegami, Y. Kawaguchi, T. Sano, and T. Ogihara, "Antioxidant, probucol, can inhibit the generation of hydrogen peroxide in islet cells induced by macrophages and prevent islet cell destruction in NOD mice," Biochemical and Biophysical Research Communications, vol. 209, no. 3, pp. 953-958, 1995.

[175] I. Batinić-Haberle, L. Benov, I. Spasojević, and I. Fridovich, "The ortho effect makes manganese(III) meso-tetrakis(Nmethylpyridinium- 2-yl)porphyrin a powerful and potentially useful superoxide dismutase mimic," Journal of Biological Chemistry, vol. 273, no. 38, pp. 24521-24528, 1998.

[176] R. F. Pasternack, A. Banth, J. M. Pasternack, and C. S. Johnson, "Catalysis of the disproportionation of superoxide by metalloporphyrins. III," Journal of Inorganic Biochemistry, vol. 15, no. 3, pp. 261-267, 1981.

[177] B. J. Day, I. Batinic-Haberle, and J. D. Crapo, "Metalloporphyrins are potent inhibitors of lipid peroxidation," Free Radical Biology and Medicine, vol. 26, no. 5-6, pp. 730-736, 1999.

[178] G. Ferrer-Sueta, D. Vitturi, I. Batinić-Haberle et al., "Reactions of manganese porphyrins with peroxynitrite and carbonate radical anion," Journal of Biological Chemistry, vol. 278, no. 30, pp. 27432-27438, 2003.

[179] Y. Huang and F. E. Domann, "Redox modulation of AP-2 DNA binding activity in vitro," Biochemical and Biophysical Research Communications, vol. 249, no. 2, pp. 307-312, 1998.

[180] YI. Sun and L. W. Oberley, "Redox regulation of transcriptional activators," Free Radical Biology and Medicine, vol. 21, no. 3, pp. 335-348, 1996.

[181] N. Giannoukakis, W. A. Rudert, M. Trucco, and P. D. Robbins, "Protection of human islets from the effects of interleukin $-1 \beta$ by adenoviral gene transfer of an $\mathrm{I} \kappa \mathrm{B}$ repressor," Journal of Biological Chemistry, vol. 275, no. 47, pp. 36509-36513, 2000.

[182] H. Heimberg, Y. Heremans, C. Jobin et al., "Inhibition of cytokine-induced NF- $\kappa$ B activation by adenovirus-mediated expression of a NF- $\kappa \mathrm{B}$ super-repressor prevents $\beta$-cell apoptosis," Diabetes, vol. 50, no. 10, pp. 2219-2224, 2001.

[183] B. D. Stadinski, T. Delong, N. Reisdorph et al., "Chromogranin A is an autoantigen in type 1 diabetes," Nature Immunology, vol. 11, no. 3, pp. 225-231, 2010.

[184] C. M. Dobbs and K. Haskins, "Comparison of a T cell clone and of T cells from a TCR transgenic mouse: TCR transgenic $\mathrm{T}$ cells specific for self-antigen are atypical," Journal of Immunology, vol. 166, no. 4, pp. 2495-2504, 2001.

[185] M. M. Sklavos, H. M. Tse, and J. D. Piganelli, "Redox modulation inhibits CD8+ T cell effector function," Free Radical Biology and Medicine, vol. 45, no. 10, pp. 1477-1486, 2008.

[186] G. Chaudhri, I. A. Clark, and N. H. Hunt, "Effect of antioxidants on primary alloantigen-induced $\mathrm{T}$ cell activation and proliferation," Journal of Immunology, vol. 137, no. 8, pp. 2646-2652, 1986.

[187] G. Chaudhri, N. H. Hunt, I. A. Clark, and R. Ceredig, "Antioxidants inhibit proliferation and cell surface expression of receptors for interleukin-2 and transferrin in $\mathrm{T}$ lymphocytes stimulated with phorbol myristate acetate and ionomycin," Cellular Immunology, vol. 115, no. 1, pp. 204213, 1988. 
[188] J. D. Malhotra, H. Miao, K. Zhang et al., "Antioxidants reduce endoplasmic reticulum stress and improve protein secretion," Proceedings of the National Academy of Sciences of the United States of America, vol. 105, no. 47, pp. 18525-18530, 2008.

[189] D. Lo, L. C. Burkly, G. Widera et al., "Diabetes and tolerance in transgenic mice expressing class II MHC molecules in pancreatic beta cells," Cell, vol. 53, no. 1, pp. 159-168, 1988.

[190] L. Jiang, F. Allagnat, E. Nguidjoe et al., "Plasma membrane Ca2+-ATPase overexpression depletes both mitochondrial and endoplasmic reticulum $\mathrm{Ca} 2+$ stores and triggers apoptosis in insulin-secreting BRIN-BD11 cells," Journal of Biological Chemistry, vol. 285, no. 40, pp. 30634-30643, 2010.

[191] X. Lei, S. Zhang, S. E. Barbour et al., "Spontaneous development of endoplasmic reticulum stress that can lead to diabetes mellitus is associated with higher calcium-independent phospholipase A expression: a role for regulation by SREBP1," Journal of Biological Chemistry, vol. 285, no. 9, pp. 6693$6705,2010$.

[192] S. Ramanadham, F.-F. Hsu, S. Zhang et al., "Apoptosis of insulin-secreting cells induced by endoplasmic reticulum stress is amplified by overexpression of group VIA calciumindependent phospholipase A2 (iPLA2 beta) and suppressed by inhibition of iPLA2 beta," Biochemistry, vol. 43, no. 4, pp. 918-930, 2004.

[193] F. R. Papa, C. Zhang, K. Shokat, and P. Waiter, "Bypassing a kinase activity with an ATP-competitive drug," Science, vol. 302, no. 5650, pp. 1533-1537, 2003.

[194] D. Ron, "Stressed cells cope with protein overload," Science, vol. 313, no. 5783, pp. 52-53, 2006.

[195] C. Patil and P. Walter, "Intracellular signaling from the endoplasmic reticulum to the nucleus: the unfolded protein response in yeast and mammals," Current Opinion in Cell Biology, vol. 13, no. 3, pp. 349-355, 2001.

[196] T. Izumi, H. Yokota-Hashimoto, S. Zhao, J. Wang, P. A. Halban, and T. Takeuchi, "Dominant negative pathogenesis by mutant proinsulin in the Akita diabetic mouse," Diabetes, vol. 52, no. 2, pp. 409-416, 2003.

[197] J. Wang, T. Takeuchi, S. Tanaka et al., "A mutation in the insulin 2 gene induces diabetes with severe pancreatic $\beta$ cell dysfunction in the Mody mouse," Journal of Clinical Investigation, vol. 103, no. 1, pp. 27-37, 1999.

[198] C. X. Santos, L. Y. Tanaka, J. Wosniak, and F. R. Laurindo, "Mechanisms and implications of reactive oxygen species generation during the unfolded protein response: roles of endoplasmic reticulum oxidoreductases, mitochondrial electron transport, and NADPH oxidase," Antioxid Redox Signal, vol. 11, pp. 2409-2427, 2009.

[199] R. J. Kaufman, "Orchestrating the unfolded protein response in health and disease," Journal of Clinical Investigation, vol. 110, no. 10, pp. 1389-1398, 2002.

[200] L. A. Casciola-Rosen, G. J. Anhalt, and A. Rosen, "DNAdependent protein kinase is one of a subset of autoantigens specifically cleaved early during apoptosis," Journal of Experimental Medicine, vol. 182, no. 6, pp. 1625-1634, 1995.

[201] S. G. Fonseca, M. Burcin, J. Gromada, and F. Urano, "Endoplasmic reticulum stress in $\beta$-cells and development of diabetes," Current Opinion in Pharmacology, vol. 9, no. 6, pp. 763-770, 2009.

[202] E. Bonifacio and A. G. Ziegler, "Advances in the prediction and natural history of type 1 diabetes," Endocrinology and Metabolism Clinics of North America, vol. 39, no. 3, pp. 513$525,2010$.
[203] A. M. Davalli, L. Scaglia, D. H. Zangen, J. Hollister, S. BonnerWeir, and G. C. Weir, "Vulnerability of islets in the immediate posttransplantation period: dynamic changes in structure and function," Diabetes, vol. 45, no. 9, pp. 1161-1167, 1996.

[204] M. M. Sklavos, S. Bertera, H. M. Tse et al., "Redox modulation protects islets from transplant-related injury," Diabetes, vol. 59, no. 7, pp. 1731-1738, 2010.

[205] M. D. Menger, P. Vajkoczy, R. Leiderer, S. Jager, and K. Messmer, "Influence of experimental hyperglycemia on microvascular blood perfusion of pancreatic islet isografts," Journal of Clinical Investigation, vol. 90, no. 4, pp. 1361-1369, 1992.

[206] W. Land, H. Schneeberger, S. Schleibner et al., "The beneficial effect of human recombinant superoxide dismutase on acute and chronic rejection events in recipients of cadaveric renal transplants," Transplantation, vol. 57, no. 2, pp. 211-217, 1994.

[207] H. Petrowsky, B. Dippe, P. Geck et al., "Do oxygen radicals play a role in primary dysfunction of transplanted livers following preservation in University of Wisconsin solution?" Transplantation Proceedings, vol. 27, no. 1, pp. 729-731, 1995.

[208] J. Mendola, J. R. Wright, and P. E. Lacy, "Oxygen freeradical scavengers and immune destruction of murine islets in allograft rejection and multiple low-dose streptozocininduced insulitis," Diabetes, vol. 38, no. 3, pp. 379-385, 1989.

[209] I. N. Nomikos, Y. Wang, and K. J. Lafferty, "Involvement of $\mathrm{O}_{2}$ radicals in 'autoimmune' diabetes," Immunology and Cell Biology, vol. 67, no. 1, pp. 85-87, 1989.

[210] Y. X. Li, GE. Li, W. P. Dong, DA. R. Lu, and J. M. Tan, "Protection of human islets from induction of apoptosis and improved islet function with $\mathrm{HO}-1$ gene transduction," Chinese Medical Journal, vol. 119, no. 19, pp. 1639-1645, 2006.

[211] S. Bertera, M. L. Crawford, A. M. Alexander et al., "Gene transfer of manganese superoxide dismutase extends islet graft function in a mouse model of autoimmune diabetes," Diabetes, vol. 52, no. 2, pp. 387-393, 2003.

[212] R. Bottino, A. N. Balamurugan, S. Bertera, M. Pietropaolo, M. Trucco, and J. D. Piganelli, "Preservation of human islet cell functional mass by anti-oxidative action of a novel SOD mimic compound," Diabetes, vol. 51, no. 8, pp. 2561-2567, 2002.

[213] A. N. Balamurugan, R. Bottino, N. Giannoukakis, and C. Smetanka, "Prospective and challenges of islet transplantation for the therapy of autoimmune diabetes," Pancreas, vol. 32, no. 3, pp. 231-243, 2006.

[214] N. Zhang, D. Su, S. Qu et al., "Sirolimus is associated with reduced islet engraftment and impaired $\beta$-cell function," Diabetes, vol. 55, no. 9, pp. 2429-2436, 2006.

[215] H. Kaneto, N. Katakami, M. Matsuhisa, and T. A. Matsuoka, "Role of reactive oxygen species in the progression of type 2 diabetes and atherosclerosis," Mediators of Inflammation, vol. 2010, Article ID 453892, 2010.

[216] S. Brahmachari and K. Pahan, "Myelin basic protein priming reduces the expression of Foxp3 in T cells via nitric oxide," Journal of Immunology, vol. 184, no. 4, pp. 1799-1809, 2010.

[217] A. Stirban, P. Rösen, and D. Tschoepe, "Complications of type 1 diabetes: new molecular findings," Mount Sinai Journal of Medicine, vol. 75, no. 4, pp. 328-351, 2008.

[218] X. Ling, A. Cota-Gomez, N. C. Flores et al., "Alterations in redox homeostasis and prostaglandins impair endothelial-dependent vasodilation in euglycemic autoimmune nonobese diabetic mice," Free Radical Biology and Medicine, vol. 39, no. 8, pp. 1089-1098, 2005. 
[219] T. Yoshikawa and N. Yoshida, "Vitamin E and leukocyteendothelial cell interactions," Antioxidants and Redox Signaling, vol. 2, no. 4, pp. 821-825, 2000.

[220] M. A. Haidara, D. P. Mikhailidis, M. A. Rateb et al., "Evaluation of the effect of oxidative stress and vitamin E supplementation on renal function in rats with streptozotocin-induced Type 1 diabetes," Journal of Diabetes and its Complications, vol. 23, no. 2, pp. 130-136, 2009. 


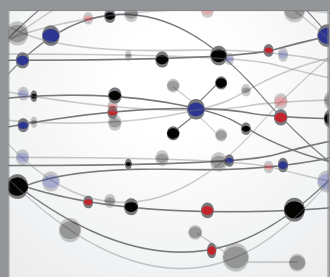

The Scientific World Journal
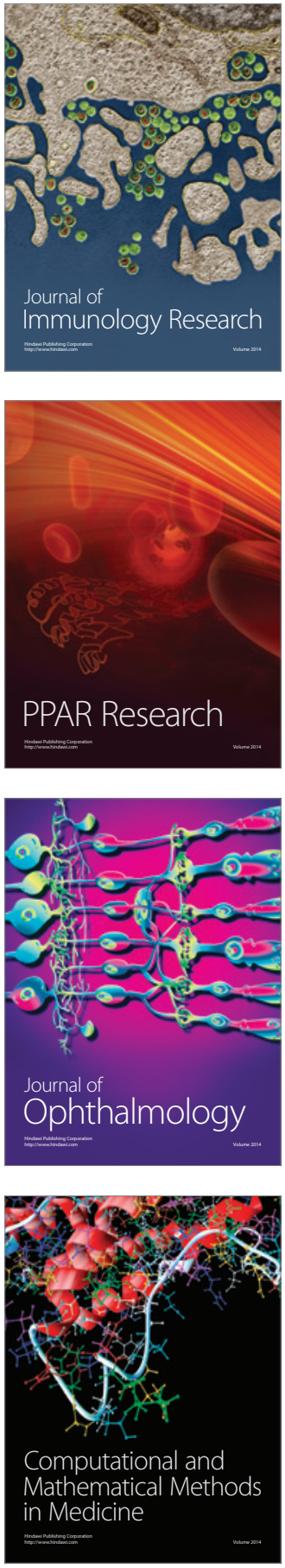

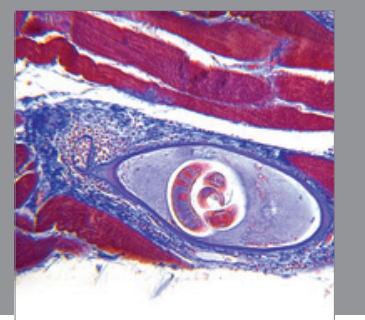

Gastroenterology

Research and Practice
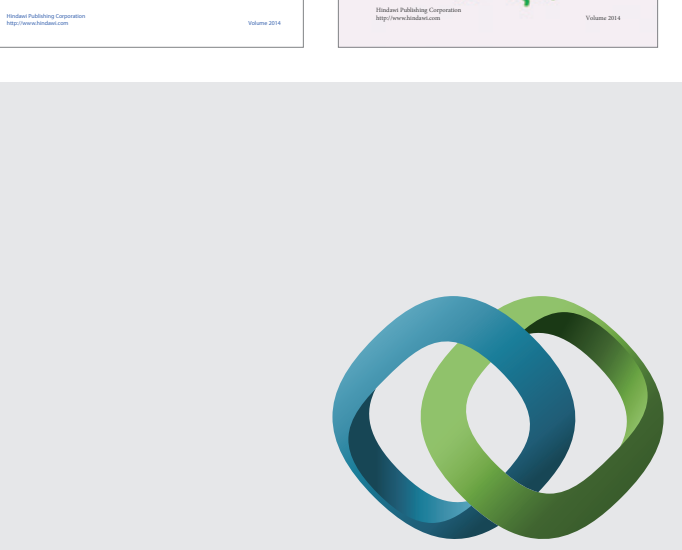

\section{Hindawi}

Submit your manuscripts at

http://www.hindawi.com
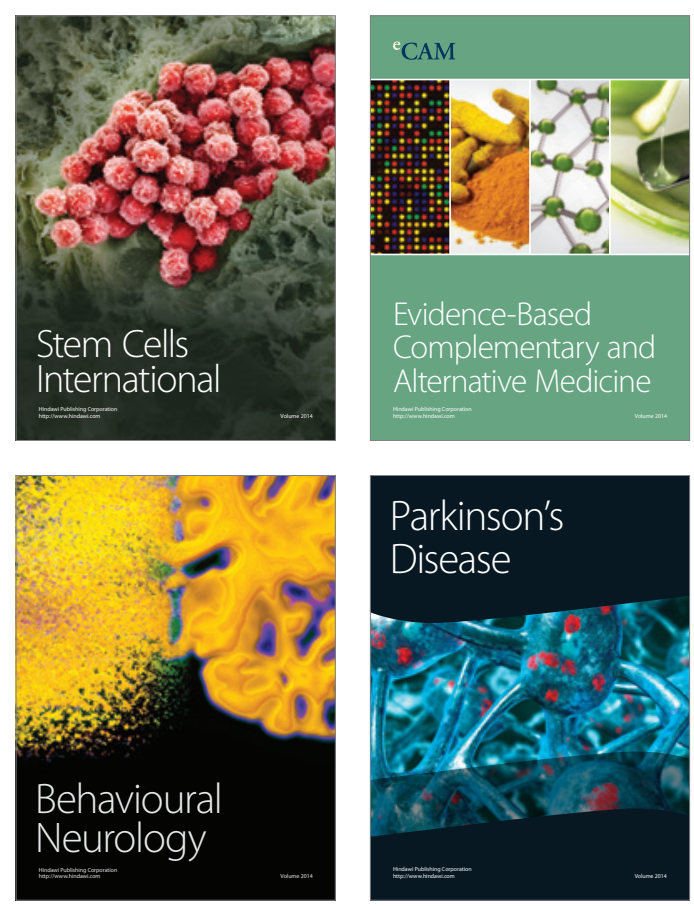

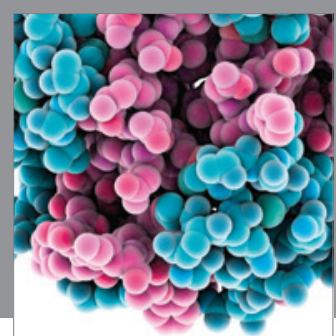

Journal of
Diabetes Research

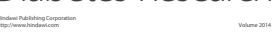

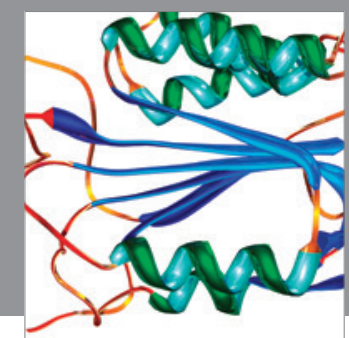

Disease Markers
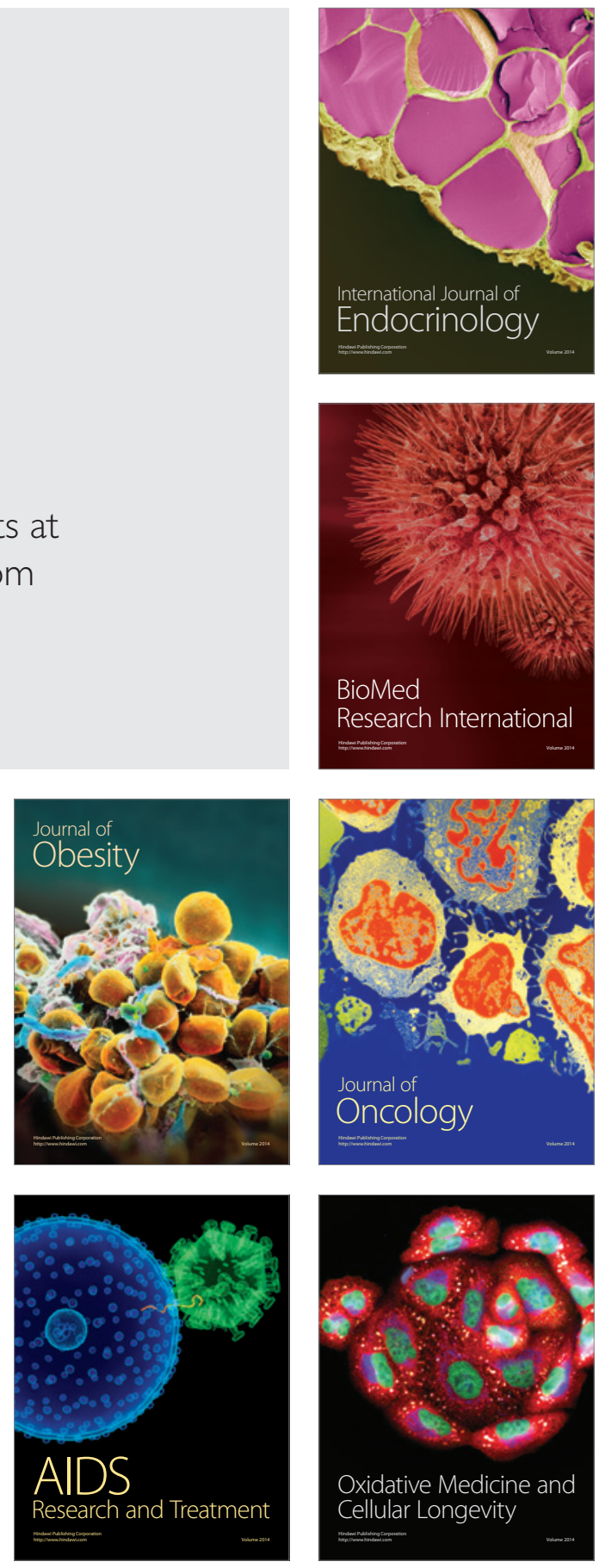